The University of Maine

\title{
DigitalCommons@UMaine
}

Earth Science Faculty Scholarship

Earth Sciences

2-18-2009

\section{Recent Increases in Atmospheric Concentrations of Bi, U, Cs, S and Ca from a 350-Year Mount Everest Ice Core Record}

\author{
Susan D. Kaspari \\ Paul Andrew Mayewski \\ University of Maine - Main, paul.mayewski@maine.edu \\ Michael Handley \\ Erich Osterberg \\ Shichang Kang \\ See next page for additional authors
}

Follow this and additional works at: https://digitalcommons.library.umaine.edu/ers_facpub

Part of the Earth Sciences Commons

\section{Repository Citation}

Kaspari, Susan D.; Mayewski, Paul Andrew; Handley, Michael; Osterberg, Erich; Kang, Shichang; Sneed, Sharon B.; Hou, Shugui; and Qin, Dahe, "Recent Increases in Atmospheric Concentrations of Bi, U, Cs, S and Ca from a 350-Year Mount Everest Ice Core Record" (2009). Earth Science Faculty Scholarship. 75.

https://digitalcommons.library.umaine.edu/ers_facpub/75

This Article is brought to you for free and open access by DigitalCommons@UMaine. It has been accepted for inclusion in Earth Science Faculty Scholarship by an authorized administrator of DigitalCommons@UMaine. For more information, please contact

um.library.technical.services@maine.edu. 
Authors

Susan D. Kaspari, Paul Andrew Mayewski, Michael Handley, Erich Osterberg, Shichang Kang, Sharon B. Sneed, Shugui Hou, and Dahe Qin 


\title{
Recent increases in atmospheric concentrations of $\mathrm{Bi}, \mathrm{U}, \mathrm{Cs}, \mathrm{S}$ and $\mathrm{Ca}$ from a 350-year Mount Everest ice core record
}

\author{
Susan Kaspari, ${ }^{1,2}$ Paul A. Mayewski, ${ }^{1,3}$ Michael Handley, ${ }^{1}$ Erich Osterberg, ${ }^{1}$ \\ Shichang Kang, ${ }^{3}$ Sharon Sneed, ${ }^{1}$ Shugui Hou, ${ }^{3}$ and Dahe Qin ${ }^{3}$ \\ Received 3 September 2008; revised 15 November 2008; accepted 5 December 2008; published 18 February 2009.
}

[1] High-resolution major and trace elements ( $\mathrm{Sr}, \mathrm{Cs}, \mathrm{Ba}, \mathrm{La}, \mathrm{Ce}, \mathrm{Pr}, \mathrm{Nd}, \mathrm{Sm}, \mathrm{Eu}, \mathrm{Tb}, \mathrm{Dy}$, Ho, Er, Tm, Yb, Lu, Bi, U, Tl, Al, S, Ca, Ti, V, Cr, Mn, Fe, and Co) quantified in a Mount Everest ice core (6518 $\mathrm{m}$ above sea level) spanning the period 1650-2002 AD provides the first Asian record of trace element concentrations from the pre-industrial era, and the first continuous high-resolution Asian record from which natural baseline concentrations and subsequent changes due to anthropogenic activities can be examined. Modern concentrations of most elements remain within the pre-industrial range; however, $\mathrm{Bi}, \mathrm{U}$, and $\mathrm{Cs}$ concentrations and their enrichment factors $(\mathrm{EF})$ have increased since the $\sim 1950 \mathrm{~s}$, and $\mathrm{S}$ and $\mathrm{Ca}$ concentrations and their EFs have increased since the late 1980s. A comparison of the $\mathrm{Bi}, \mathrm{U}, \mathrm{Cs}, \mathrm{S}$, and $\mathrm{Ca}$ data with other ice core records and production data indicates that the increase in atmospheric concentrations of trace elements is widespread, but that enrichment varies regionally. Likely sources for the recent enrichment of these elements include mining, metal smelting, oil and coal combustion, and end uses for $\mathrm{Bi}$, and mining and refinement for $\mathrm{U}$ and Cs. The source of the synchronous enrichment of $\mathrm{Ca}$ and $\mathrm{S}$ is less certain, but may be related to land use and environmental change.

Citation: Kaspari, S., P. A. Mayewski, M. Handley, E. Osterberg, S. Kang, S. Sneed, S. Hou, and D. Qin (2009), Recent increases in atmospheric concentrations of $\mathrm{Bi}, \mathrm{U}, \mathrm{Cs}, \mathrm{S}$ and Ca from a 350-year Mount Everest ice core record, J. Geophys. Res., 114, D04302, doi:10.1029/2008JD011088.

\section{Introduction}

[2] Trace elements exist naturally in the Earth's environment in low concentrations. However, human activities including fossil fuel combustion, metal smelting, industry, agriculture, mining, construction and large-scale land use change result in emission of some elements in concentrations greater than natural background levels [Nriagu and Davidson, 1986]. This can alter the rate at which elements are transported among different reservoirs, and the form in which the elements exist. These elements, particularly as fine particles, are subject to transport within air masses far from their emission sources, and can subsequently move through ecosystems with adverse effects for the environment and human health depending upon their bioavailability and toxicity [Pacyna and Pacyna, 2001].

[3] In recent decades efforts have been made to assess trace element pollution via monitoring programs and by conducting emission inventories [Nriagu and Pacyna, 1988;

\footnotetext{
${ }^{1}$ Climate Change Institute and Department of Earth Sciences, University of Maine, Orono, Maine, USA.

${ }^{2}$ Now at Laboratory for Radiochemistry and Environmental Chemistry, Paul Scherrer Institute, Villigen, Switzerland.

${ }^{3}$ State Joint Key Laboratory of Cryospheric and Environment, Chinese Academy of Sciences, Beijing, China.

Copyright 2009 by the American Geophysical Union. 0148-0227/09/2008JD011088
}

Pacyna and Pacyna, 2001]. Because these studies only cover time periods on the order of weeks to the last two to three decades, they do not allow a comparison with preindustrial levels to put recent changes into perspective. Information on past changes of atmospheric concentrations of trace elements and metals prior to the last few decades can only be obtained from natural archives such as peat bogs, lake sediments, or ice cores [Barbante et al., 2004]. Ice cores recovered from appropriately chosen sites are an ideal archive for reconstructing the past composition of the atmosphere because they provide high-resolution, wellpreserved, multiparameter archives of the atmospheric signature from remote regions, including information about past temperature, precipitation, atmospheric circulation, and atmospheric chemistry. Owing to differences in the sources, transport and residence time of trace elements in the atmosphere, the composition and concentration of elements can vary greatly region to region, and with elevation. Thus, a spatial array of natural archives is needed to effectively assess spatial and temporal changes in the metal and trace element loading of the atmosphere.

[4] Increased 20th century concentrations relative to preindustrial levels are reported from ice core records for $\mathrm{Pb}, \mathrm{Cd}$ [Boutron et al., 1995; Candelone et al., 1995; McConnell and Edwards, 2008], $\mathrm{Cu}, \mathrm{Zn}$ [Boutron et al., 1995; Candelone et al., 1995], Tl [McConnell and Edwards, 2008], $\mathrm{NO}_{3}^{-}$and $\mathrm{SO}_{4}^{2-}$ in Greenland [Fischer et al., 1998; Goto-Azuma and Koerner, 2001; Mayewski et al., 1990]; 


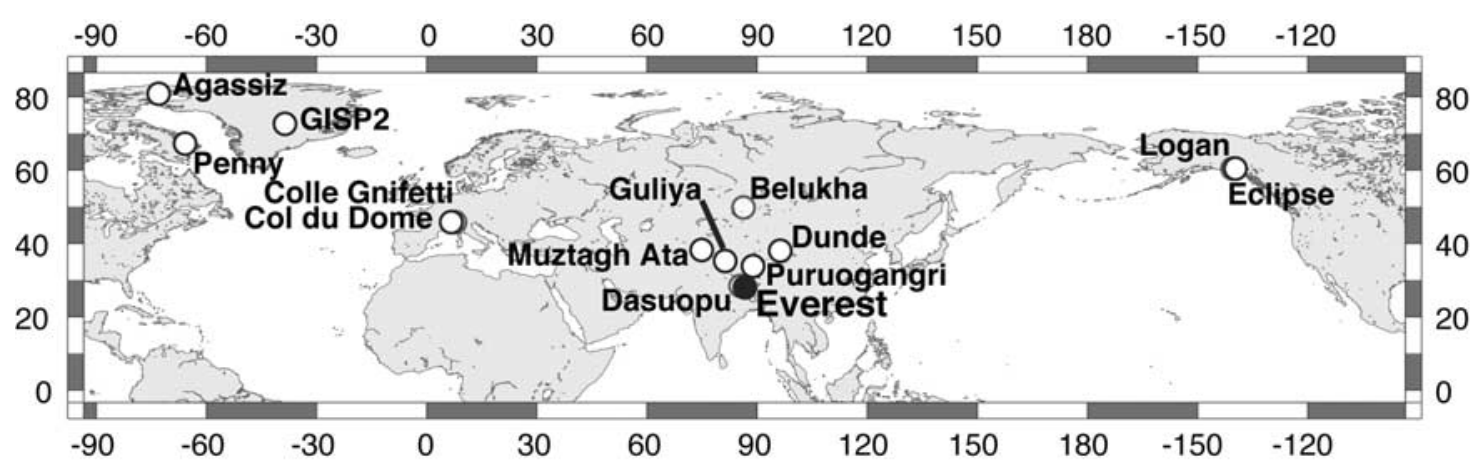

Figure 1. Location map of the Mount Everest ice core drill site (solid black circle), and other ice core sites mentioned in the text (white circles).

$\mathrm{NO}_{3}^{-}$and $\mathrm{SO}_{4}^{2-}$ in the Arctic [Goto-Azuma and Koerner, 2001]; $\mathrm{Pb}$ [Boutron and Patterson, 1983], $\mathrm{Cr}, \mathrm{Cu}, \mathrm{Zn}, \mathrm{Ag}$, $\mathrm{Pb}, \mathrm{Bi}, \mathrm{U}$ [Planchon et al., 2002] and $\mathrm{NO}_{3}^{-}$[Mayewski and Legrand, 1990] in Antarctica; U [Barbante et al., 2001] Cd, $\mathrm{Cu}, \mathrm{Zn}$ [Van de Velde et al., 2000; Barbante et al., 2004] Bi, $\mathrm{Ni}, \mathrm{Co}, \mathrm{Cr}, \mathrm{Mo}, \mathrm{Sb}$ [Barbante et al., 2004], Pb [Schwikowski et al., 2004], $\mathrm{NO}_{3}^{-}$[Preunkert et al., 2003] and $\mathrm{SO}_{4}^{2-}$ [Preunkert et al., 2001; Schwikowski et al., 1999b] in the European Alps; $\mathrm{NO}_{3}^{-}$and $\mathrm{SO}_{4}^{2-}$ in the Siberian Altai [Olivier et al., 2006]; $\mathrm{SO}_{4}^{2-}$ in the Himalayas [Duan et al., 2007]; and $\mathrm{Pb}$ [Osterberg et al., 2008], Bi [Osterberg, 2007], $\mathrm{NO}_{3}^{-}$and $\mathrm{SO}_{4}^{2-}$ in the Yukon [Yalcin and Wake, 2001]. Many of these studies have also documented a decrease in trace and major element concentrations in recent decades (e.g., $\mathrm{Pb}$ [Boutron et al., 1991], Cd, $\mathrm{Zn}$ [Van de Velde et al., 2000] and $\mathrm{SO}_{4}^{2-}$ [Fischer et al., 1998; Preunkert et al., 2001, Schwikowski et al., 1999a, 1999b]) due to control of industrial emissions and declined use of $\mathrm{Pb}$ gasoline additives.

[5] Asia is estimated to be the largest source of anthropogenic emissions of atmospheric trace metals due to growing demands for energy in the region, increasing industrial production, and less stringent emission controls [Pacyna and Pacyna, 2001]. Many of the Asian countries (e.g., China, Japan, Korea) that have the largest emissions of atmospheric trace metals are located downwind of the mountain regions from which glaciochemical records can be collected. Thus, depending on the location and length of the record, glaciochemical records from the Himalayas and Tibetan Plateau and surrounding mountain regions may provide records of anthropogenic emissions from India and central Asia since industrialization, and of the natural background composition of the atmosphere prior to industrialization. However, trace element measurements in snow and ice from Asia remain scarce. Previous research in Asia includes determination of $\mathrm{Pb}$ concentrations in three snow pits from the Tibetan Plateau [Xiao et al., 2001]; $\mathrm{Cd}$ and $\mathrm{Pb}$ concentrations in a 2-m ice core from the Malan glacier, Tibetan Plateau [Li et al., 2002]; $\mathrm{Mn}, \mathrm{Cu}, \mathrm{Zn}, \mathrm{Rb}, \mathrm{Sr}, \mathrm{Cd}$, $\mathrm{Ba}, \mathrm{Pb}$ and $\mathrm{U}$ concentrations in $0.42 \mathrm{~m}$ of firn from the Altai [Nikolaeva et al., 2003]; Al, S, Ti, Fe, Mn, V, Cr, Co, Cu, $\mathrm{Zn}, \mathrm{As}, \mathrm{Se}, \mathrm{Sr}, \mathrm{Mo}, \mathrm{Cd}, \mathrm{Sb}, \mathrm{Cs}, \mathrm{Ba}, \mathrm{Tl}, \mathrm{Pb}, \mathrm{Bi}$ and $\mathrm{U}$ concentrations in surface snow samples and a $3.5 \mathrm{~m}$ firn core from Mount Everest [Kang et al., 2007]; and major and rare earth element ( $\mathrm{Al}, \mathrm{Fe}, \mathrm{Ca} \mathrm{S}, \mathrm{La}, \mathrm{Ce}, \mathrm{Pr}, \mathrm{Nd}, \mathrm{Sm}, \mathrm{Eu}$, $\mathrm{Gd}, \mathrm{Tb}, \mathrm{Dy}, \mathrm{Ho}, \mathrm{Er}, \mathrm{Tb}$ and $\mathrm{Lu}$ ) concentrations on the
Inilchek ice core from the Tien Shan for the period 1992 1998 [Kreutz and Sholkovitz, 2000]. The longest record of trace elements ( $\mathrm{Al}, \mathrm{Mn}, \mathrm{Rb}, \mathrm{Sr}, \mathrm{Ba}, \mathrm{Cs}, \mathrm{Bi}$ and $\mathrm{Sb})$ is from the Muztagh Ata ice core from the Pamirs spanning the mid1950s to 2000. This record demonstrated increasing concentrations of $\mathrm{Sb}$ and $\mathrm{Bi}$ from the mid-1960s to the early 1990s [Li et al., 2006]. The only Asian ice core records long enough to document changes in the composition of the atmosphere related to anthropogenic activities are from Dasuopu and Everest in the Himalayas. These records demonstrated a 20th century increase in $\mathrm{SO}_{4}^{2-}, \mathrm{NH}_{4}^{+}$and $\mathrm{C}_{2} \mathrm{O}_{4}^{2-}$ concentrations [Duan et al., 2007; Hou et al., 2003; Kang et al., 2002b].

[6] Since 1997 four ice cores have been collected and analyzed from the Everest region, making it one of the most thoroughly studied and best understood subpolar coring sites [Hou et al., 2002; Kang et al., 2002a; Kaspari et al., 2007]. Here we present the results of major and trace element analyses made on a Mount Everest ice core (Figure 1). This provides the first Asian record of trace element concentrations from the Pre-Industrial Era, and the first continuous high-resolution Asian record. Herein we use the Everest record to determine natural baseline concentrations of atmospheric trace elements and subsequent changes due to anthropogenic activities. More elements have been quantified in the Everest ice core in this study than any previous Asian ice core. The resultant record provides an excellent context in which to investigate variations in the chemical composition of the mid-upper troposphere since $1650 \mathrm{AD}$.

\section{Methods}

[7] In 2002 as part of a joint Chinese-American program, a 108-m-long ice core drilled to bedrock was recovered from the col of the East Rongbuk glacier located on the northeast ridge of Mount Everest $\left(28.03^{\circ} \mathrm{N}, 86.96^{\circ} \mathrm{E}, 6518 \mathrm{~m}\right.$ asl $)$ (Figure 1). The borehole temperature at the bottom of the core was $-8.9^{\circ} \mathrm{C}$, indicating that the glacier is frozen at the bed. Repeat GPS surveys in 1998 and 2002 at the col drill site did not detect horizontal movement of the glacier, indicating minimal flow deformation yielding an undeformed record. The mean accumulation rate at the site as calculated from density profiles and annual layer thicknesses is $52 \mathrm{~cm}$ w.e. $\mathrm{a}^{-1}$ [Kaspari et al., 2007, 2008]. 
Table 1. Detection Limits, Element Concentrations, Enrichment Factors, and Increase Factor Analysis for the Mount Everest Ice Core ${ }^{\mathrm{a}}$

\begin{tabular}{|c|c|c|c|c|c|c|c|c|c|c|c|}
\hline & IDL & $\begin{array}{c}\text { Method } \\
\text { Blank }\end{array}$ & MDL & $\begin{array}{l}1650- \\
1800 \\
\text { Median }\end{array}$ & $\begin{array}{l}1800- \\
1950 \\
\text { Median }\end{array}$ & $\begin{array}{l}1950- \\
2002 \\
\text { Median }\end{array}$ & $\begin{array}{l}1970- \\
2002 \\
\text { Median }\end{array}$ & $\begin{array}{c}1950-2002 \\
1650-1800 \\
\text { Increase Factor }\end{array}$ & $\begin{array}{c}1970-2002 \\
1650-1800 \\
\text { Increase Factor }\end{array}$ & $\begin{array}{c}1950-2002 \\
1800-1950 \\
\text { Increase Factor }\end{array}$ & $\begin{array}{c}1970-2002 \\
1800-1950 \\
\text { Increase Factor }\end{array}$ \\
\hline $\mathrm{Al}(\mathrm{ppb})$ & 0.04 & $3.19 \pm 0.33$ & 1.00 & 36.6 & 47.0 & 40.1 & 44.0 & 1.1 & 1.2 & 0.9 & 0.9 \\
\hline$S(p p b)$ & 0.29 & $0.78 \pm 0.46$ & 1.37 & 8.1 & 10.3 & 13.5 & 18.4 & 1.7 & 2.3 & 1.3 & 1.8 \\
\hline $\mathrm{Ca}(\mathrm{ppb})$ & 0.11 & $2.90 \pm 1.11$ & 3.33 & 79.3 & 111.5 & 153.3 & 193.8 & 1.9 & 2.4 & 1.4 & 1.7 \\
\hline $\mathrm{Ti}(\mathrm{ppt})$ & 0.7 & $9.3 \pm 2.5$ & 7.6 & 3360 & 3860 & 4620 & 4930 & 1.4 & 1.5 & 1.2 & 1.3 \\
\hline $\mathrm{V}(\mathrm{ppt})$ & 0.1 & $2.1 \pm 0.8$ & 2.4 & 74.1 & 90.3 & 97.1 & 105.5 & 1.3 & 1.4 & 1.1 & 1.2 \\
\hline $\mathrm{Cr}(\mathrm{ppt})$ & 0.14 & $1.66 \pm 1.49$ & 4.46 & 77.3 & 95.3 & 95.4 & 106.6 & 1.2 & 1.4 & 1.0 & 1.1 \\
\hline $\mathrm{Mn}$ (ppt) & 1 & $68 \pm 30$ & 90 & 1300 & 1510 & 1750 & 2010 & 1.3 & 1.5 & 1.2 & 1.3 \\
\hline $\mathrm{Fe}(\mathrm{ppb})$ & 0.01 & $0.38 \pm 0.23$ & 0.69 & 55.4 & 64.3 & 57.8 & 61.9 & 1.0 & 1.1 & 0.9 & 1.0 \\
\hline Co (ppt) & 0.41 & $1.45 \pm 0.38$ & 1.15 & 26.2 & 32.5 & 35.9 & 39.2 & 1.4 & 1.5 & 1.1 & 1.2 \\
\hline $\mathrm{Sr}$ (ppt) & 0.3 & $10.0 \pm 1.5$ & 4.4 & 288.5 & 351.2 & 371.2 & 430.0 & 1.3 & 1.5 & 1.1 & 1.2 \\
\hline Cs (ppt) & 0.007 & $0.202 \pm 0.106$ & 0.317 & 53.3 & 68.1 & 102.0 & 112.1 & 1.9 & 2.1 & 1.5 & 1.6 \\
\hline $\mathrm{Ba}(\mathrm{ppt})$ & 0.33 & $19.99 \pm 5.97$ & 17.92 & 289.8 & 331.3 & 343.8 & 379.9 & 1.2 & 1.3 & 1.0 & 1.1 \\
\hline $\mathrm{La}(\mathrm{ppt})$ & 0.01 & $0.05 \pm 0.03$ & 0.08 & 12.8 & 15.2 & 15.9 & 19.7 & 1.2 & 1.5 & 1.0 & 1.3 \\
\hline $\mathrm{Ce}(\mathrm{ppt})$ & 0.01 & $0.03 \pm 0.03$ & 0.08 & 28.6 & 33.1 & 34.1 & 37.4 & 1.2 & 1.3 & 1.0 & 1.1 \\
\hline $\operatorname{Pr}(\mathrm{ppt})$ & 0.002 & $0.007 \pm 0.006$ & 0.017 & 3.6 & 4.1 & 4.4 & 4.8 & 1.2 & 1.3 & 1.1 & 1.2 \\
\hline $\mathrm{Nd}(\mathrm{ppt})$ & 0.012 & $0.029 \pm 0.021$ & 0.064 & 14.6 & 16.7 & 17.4 & 19.2 & 1.2 & 1.3 & 1.0 & 1.1 \\
\hline $\mathrm{Sm}$ (ppt) & 0.006 & $<\mathrm{IDL}$ & $<\mathrm{IDL}$ & 3.6 & 4.3 & 4.6 & 5.3 & 1.3 & 1.5 & 1.1 & 1.2 \\
\hline $\mathrm{Eu}(\mathrm{ppt})$ & 0.003 & $0.027 \pm 0.008$ & 0.024 & 0.7 & 0.9 & 1.1 & 1.2 & 1.4 & 1.6 & 1.1 & 1.3 \\
\hline $\mathrm{Tb}(\mathrm{ppt})$ & 0.001 & $0.010 \pm 0.000$ & 0.001 & 0.5 & 0.7 & 0.7 & 0.9 & 1.4 & 1.6 & 1.1 & 1.3 \\
\hline Dy (ppt) & 0.011 & $<\mathrm{IDL}$ & $<\mathrm{IDL}$ & 3.2 & 3.7 & 4.1 & 5.4 & 1.3 & 1.7 & 1.1 & 1.4 \\
\hline Но (ppt) & 0.001 & $0.002 \pm 0.001$ & 0.004 & 0.6 & 0.7 & 0.8 & 1.0 & 1.4 & 1.8 & 1.2 & 1.5 \\
\hline $\operatorname{Er}(\mathrm{ppt})$ & 0.005 & $<\mathrm{IDL}$ & $<\mathrm{IDL}$ & 1.5 & 1.7 & 2.2 & 2.5 & 1.4 & 1.7 & 1.3 & 1.5 \\
\hline $\operatorname{Tm}(\mathrm{ppt})$ & 0.002 & $0.004 \pm 0.001$ & 0.003 & 0.2 & 0.2 & 0.3 & 0.4 & 1.3 & 1.7 & 1.2 & 1.5 \\
\hline $\mathrm{Yb}(\mathrm{ppt})$ & 0.01 & $<\mathrm{IDL}$ & $<\mathrm{IDL}$ & 1.2 & 1.4 & 1.8 & 2.2 & 1.5 & 1.9 & 1.2 & 1.6 \\
\hline $\mathrm{Lu}(\mathrm{ppt})$ & 0.005 & $<\mathrm{IDL}$ & $<\mathrm{IDL}$ & 0.2 & 0.2 & 0.3 & 0.3 & 1.6 & 1.9 & 1.3 & 1.6 \\
\hline $\mathrm{Tl}(\mathrm{ppt})$ & 0.03 & $0.06 \pm 0.03$ & 0.09 & 1.2 & 1.4 & 1.7 & 1.9 & 1.4 & 1.6 & 1.2 & 1.4 \\
\hline $\mathrm{Bi}(\mathrm{ppt})$ & 0.03 & $<\mathrm{IDL}$ & $<\mathrm{IDL}$ & 2.2 & 2.9 & 5.4 & 7.1 & 2.5 & 3.2 & 1.9 & 2.5 \\
\hline $\mathrm{U}(\mathrm{ppt})$ & 0.006 & $0.75 \pm 0.19$ & 0.57 & 6.0 & 8.0 & 19.1 & 24.7 & 3.2 & 4.1 & 2.4 & 3.1 \\
\hline $\mathrm{Al} \mathrm{EF}$ & & & & 0.3 & 0.4 & 0.3 & 0.3 & 0.9 & 0.9 & 0.8 & 0.9 \\
\hline S EF & & & & 7.9 & 8.6 & 10.9 & 15.8 & 1.4 & 2.0 & 1.3 & 1.8 \\
\hline $\mathrm{Ca} \mathrm{EF}$ & & & & 2.5 & 2.9 & 3.4 & 4.3 & 1.3 & 1.7 & 1.2 & 1.5 \\
\hline Ti EF & & & & 1.5 & 1.4 & 1.8 & 1.7 & 1.2 & 1.2 & 1.2 & 1.2 \\
\hline $\mathrm{V}$ EF & & & & 1.2 & 1.3 & 1.2 & 1.2 & 1.0 & 1.0 & 0.9 & 1.0 \\
\hline $\mathrm{Cr} \mathrm{EF}$ & & & & 1.9 & 2.0 & 1.9 & 1.9 & 1.0 & 1.0 & 0.9 & 0.9 \\
\hline $\mathrm{Mn}$ EF & & & & 2.2 & 2.1 & 2.1 & 2.2 & 1.0 & 1.0 & 1.0 & 1.0 \\
\hline $\mathrm{Fe} \mathrm{EF}$ & & & & 2.7 & 2.5 & 2.5 & 2.4 & 0.9 & 0.9 & 1.0 & 1.0 \\
\hline Co EF & & & & 2.0 & 2.2 & 2.1 & 2.2 & 1.0 & 1.1 & 1.0 & 1.0 \\
\hline Sr EF & & & & 0.9 & 0.9 & 0.8 & 0.9 & 0.9 & 1.0 & 0.9 & 1.0 \\
\hline Cs EF & & & & 8.5 & 9.4 & 13.1 & 14.3 & 1.6 & 1.7 & 1.4 & 1.5 \\
\hline $\mathrm{Ba} E F$ & & & & 0.4 & 0.4 & 0.3 & 0.4 & 0.9 & 0.9 & 0.9 & 0.9 \\
\hline La EF & & & & 0.4 & 0.4 & 0.4 & 0.4 & 1.0 & 1.2 & 1.0 & 1.1 \\
\hline $\mathrm{Tl} \mathrm{EF}$ & & & & 1.5 & 1.5 & 1.6 & 1.6 & 1.1 & 1.1 & 1.0 & 1.1 \\
\hline $\mathrm{Bi} \mathrm{EF}$ & & & & 15.7 & 19.1 & 33.3 & 36.8 & 2.1 & 2.3 & 1.7 & 1.9 \\
\hline U EF & & & & 2.2 & 2.5 & 5.8 & 7.1 & 2.6 & 3.2 & 2.3 & 2.8 \\
\hline
\end{tabular}

${ }^{\mathrm{a}} \mathrm{EF}$ denotes enrichment factors. Median concentrations and EFs are based on the data resampled to four samples per year. IDL is instrument detection limit [Osterberg et al., 2006]. The method blank is the mean of 10 DI water samples passed through the melter system, and the method detection limit (MDL) is calculated by $3 \sigma$ of 10 DI water samples passed through the melter system. Italicized entries denote elements with a significant increase factor.

[8] The ice core was shipped frozen to the University of Maine for processing and analyses. The ice was melted into discrete samples at 3-4 $\mathrm{cm}$ resolution using an aluminum melter head with the University of Maine's continuous melter system with discrete sampling (CMDS) [Osterberg et al., 2006]. The melter head splits the meltwater into two different channels; meltwater from the outer portion of the ice core is collected in an outer channel for determination of stable isotopes, and meltwater from the innermost section of the ice core is collected in an inner channel for determination of major ions and trace elements. The sample water is pumped into: acid-precleaned, PP vials for ICP-SFMS measurements; DI precleaned vials for major ion measurements; and high-density polyethylene vials for stable isotope measurements. Detailed information on the melter system and analytical techniques is provided by Osterberg et al. [2006]. At the University of Maine the ice core samples were quantifie major ions $\left(\mathrm{Na}^{+}, \mathrm{K}^{+}, \mathrm{Mg}^{2+}\right.$,
$\left.\mathrm{Ca}^{2+}, \mathrm{Cl}^{-}, \mathrm{NO}_{3}^{-}, \mathrm{SO}_{4}^{2-}\right)$ via ion chromatography, stable isotopes $(\delta \mathrm{D})$ via isotope ratio mass spectrometry, and trace elements ( $\mathrm{Al}, \mathrm{S}, \mathrm{Ca}, \mathrm{Ti}, \mathrm{V}, \mathrm{Cr}, \mathrm{Mn}, \mathrm{Fe}, \mathrm{Co}, \mathrm{Sr}, \mathrm{Cs}, \mathrm{Ba}, \mathrm{La}$, $\mathrm{Ce}, \mathrm{Pr}, \mathrm{Nd}, \mathrm{Sm}, \mathrm{Eu}, \mathrm{Tb}, \mathrm{Dy}, \mathrm{Ho}, \mathrm{Er}, \mathrm{Tm}, \mathrm{Yb}, \mathrm{Lu}, \mathrm{Tl}, \mathrm{Bi}, \mathrm{U})$ via inductively coupled plasma sector field mass spectrometry (ICP-SFMS). The ICP-SFMS samples were acidified to $1 \% \mathrm{HNO}_{3}$ and allowed to react with the acid for 7 days, and then frozen until measured. Just prior to being measured the samples were spiked to contain $1 \mathrm{ppb}$ Indium as an internal standard. Instrument and method detection levels are reported in Table 1. The ICP-SFMS data were blank corrected by subtracting the method blank values. Samples with concentrations below the method blank values (1.0 $2.5 \%$ of samples depending on the element) were substituted with concentrations equal to half the method blank value.

[9] Owing to the relatively high accumulation rate $\left(52 \mathrm{~cm} \mathrm{a}^{-1}\right)$, seasonal variations in $\delta \mathrm{D}$, soluble ions and trace elements are well preserved in the core, and were used 


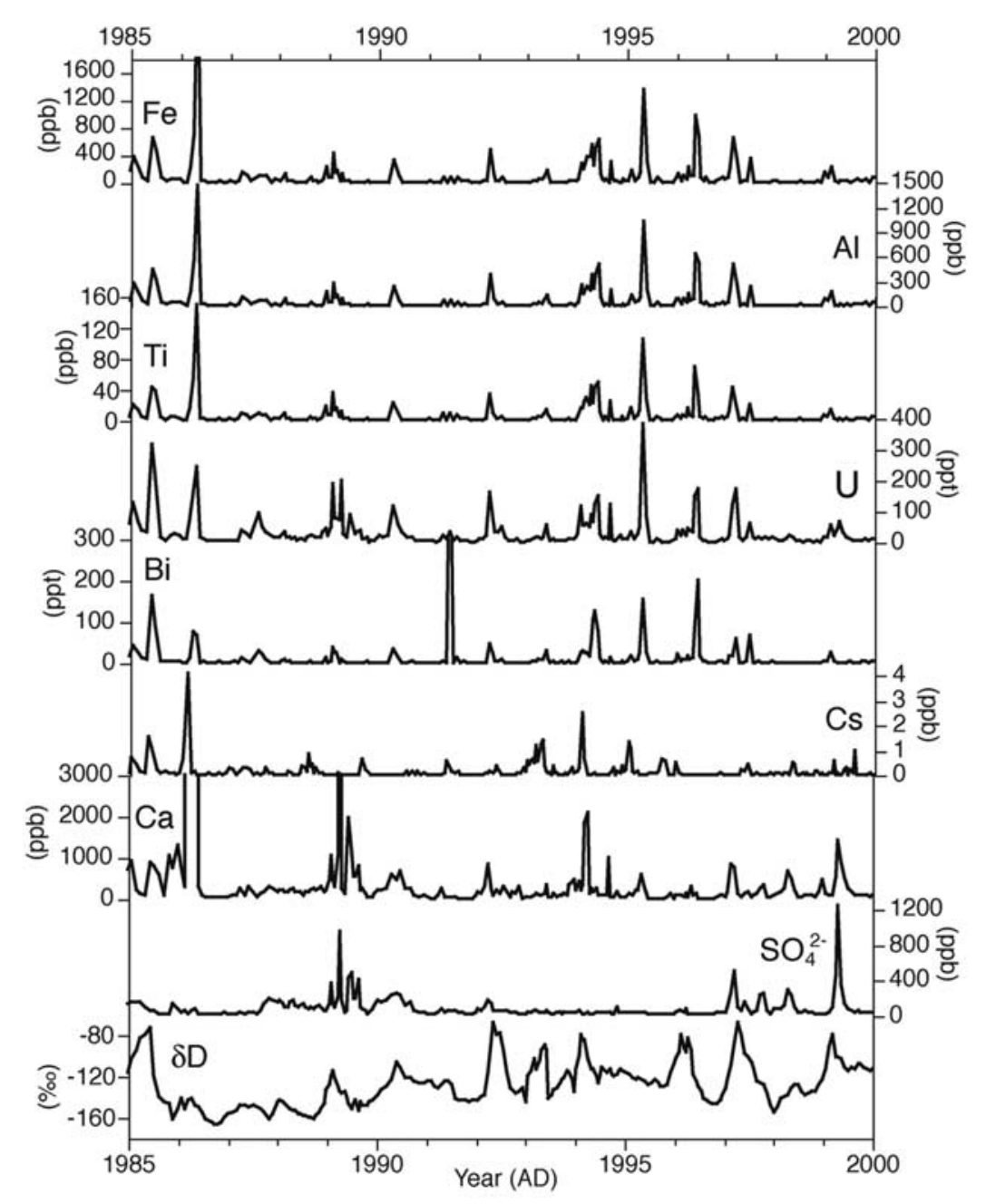

Figure 2. High-resolution Mount Everest ice core data showing seasonal variations in Fe, Al, Ti, U, Bi, $\mathrm{Cs}, \mathrm{Ca}, \mathrm{SO}_{4}^{2-}$, and $\delta \mathrm{D}$.

to date the ice core by counting annual layers (Figure 2). Dust source elements (e.g., $\mathrm{Fe}, \mathrm{Al}, \mathrm{Ti}, \mathrm{Ca}$ ) in this region peak during the winter and spring owing to unstable atmospheric conditions and strong winds. Strong monsoon activity during the summer results in more depleted heavy isotopes (more negative $\delta$ D) [Tian et al., 2001, 2003]. The timescale was verified by using the first high-resolution measurements of Bismuth (Bi) on an Asian ice core to identify major volcanic horizons, including Pinatubo (1991), Agung (1963) and Tambora (1815) [Kaspari et al., 2007]. Dating uncertainties are estimated to be \pm 0 years at 1963 (20 samples per year) based on a volcanic Bi horizon from the Agung eruption, and \pm 5 years at 1534 (4 samples per year) based on repeat annual layer counting. Kaspari et al. [2007, 2008] provide more detailed information on the depth-age scale. Here we focus on the record since $1650 \mathrm{AD}$.

\section{Results and Discussion}

\subsection{Seasonal Variability}

[10] Examination of the highly resolved ( $\sim 15-20$ samples per year between 1950 and 2002; $\sim 5$ samples per year between 1650 and 1700) Mount Everest ice core record demonstrates seasonal ions in trace elements trans- ported to Mount Everest. The dominant source of these elements is from rock and soil dust from the arid regions of Southwest Asia, the Arabian Peninsula, and the Northern Sahara that is entrained into the atmosphere [Kang et al., 2004, 2007; Kaspari et al., 2009; Wake et al., 1993]. As mentioned previously, concentrations peak during the winter and spring due to high winds and more turbulent atmospheric circulation, resulting in a distinct seasonal peak in the glaciochemical record (Figure 2). Atmospheric circulation in the region is dominated by the westerlies during winter-spring, thus the dominant source of dust and other aerosols is from regions west of Mount Everest. The timing of peak dust input in the winter-spring is verified by a comparison with the seasonality of hydrogen isotopes $(\delta \mathrm{D})$. The $\delta \mathrm{D}$ is most negative during the summer monsoon season owing to the precipitation "amount effect", during which heavy isotopes are depleted relative to light isotopes during periods of high precipitation [Kaspari et al., 2007; Tian et al., 2001, 2003].

\subsection{Variations in Element Concentrations and Enrichment Factors Since 1650 AD}

[11] We examine the Mount Everest ice core record for changes in concentrations of trace elements since $1650 \mathrm{AD}$. 

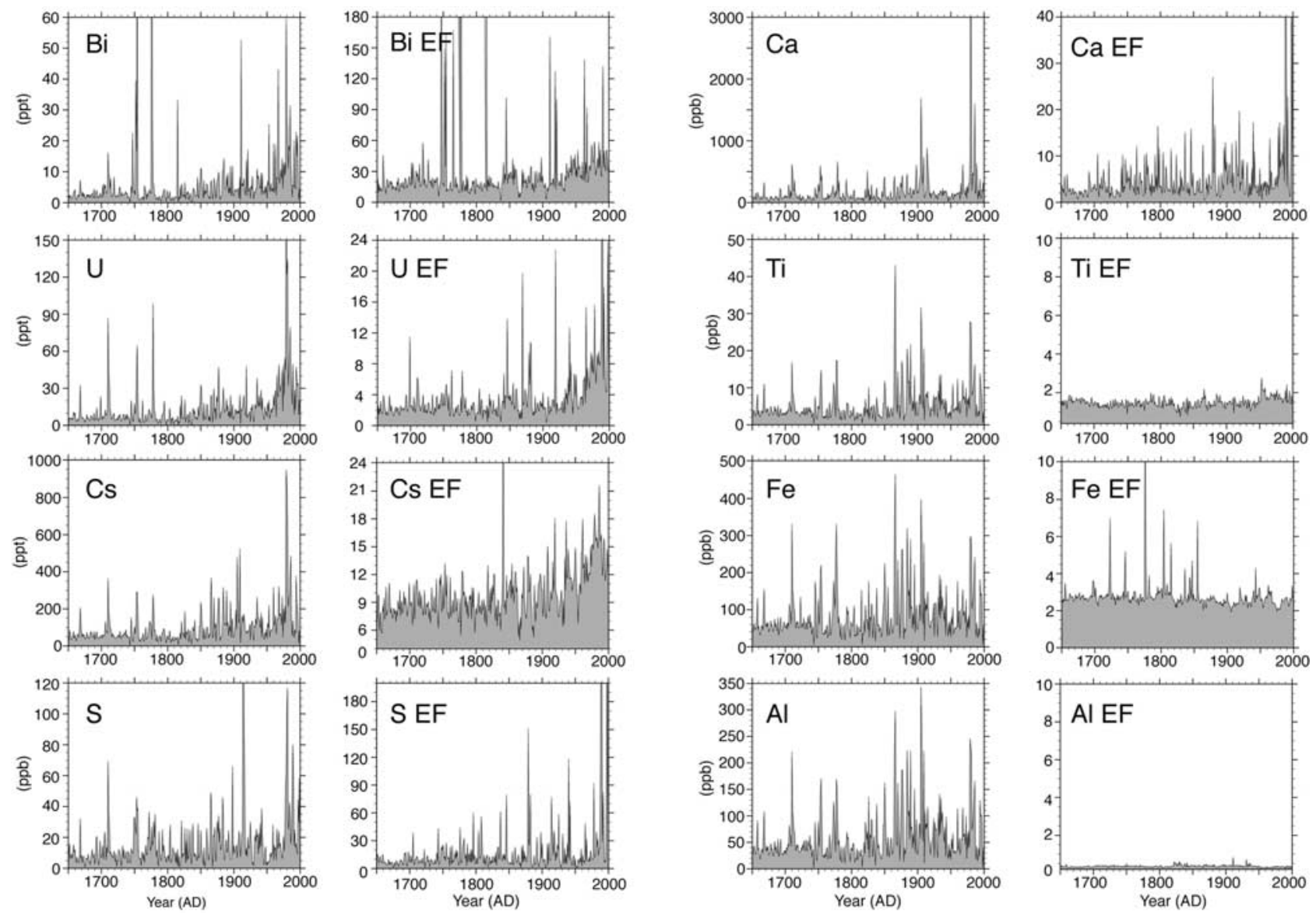

Figure 3. Mount Everest annual Bi, U, Cs, S, Ca, Ti, Fe, and Al concentration and EF data from 1650 to 2002. Note the difference in EF scales between elements.

The data is smoothed to four samples per year resolution to account for differences in sampling resolution with depth in the ice core. Natural variations in element concentrations on seasonal to multiannual timescales occur owing to natural changes in sources and transport of dust (Figure 3), and is discussed in detail elsewhere [Kaspari et al., 2009]. Here we focus on investigating if anthropogenic activities associated with industrialization are changing the chemical composition and trace element loading of the atmosphere. We use median rather than mean values in our analysis to prevent outliers from skewing the results. Median element concentrations post-1950 are unchanged or slightly higher relative to element concentrations from 1650 to 1800 for most elements (Table 1). The most notable increases post1950 are in Bi and $\mathrm{U}$ (Table 1 and Figure 3), with twofold and threefold increases in median concentrations, respectively. The large peaks in the Bi record are from volcanic Bi from large volcanic eruptions [Kaspari et al., 2007]. Smaller concentration increases are observed in $\mathrm{Cs}, \mathrm{Ca}$ and $\mathrm{S}$ (Table 1 and Figure 3 ).

[12] Because the higher element concentrations post-1950 relative to $1650-1800$ could be related to natural variations in atmospheric dust concentrations rather than anthropogenic activities, we calculate the crustal enrichment factor (EF),

$\mathrm{EF}(\mathrm{X})=(\mathrm{X} / \text { Crustal Element })_{\text {sample }} /(\mathrm{X} / \text { Crustal Element })_{\text {reference }}$, where $\mathrm{X}$ is the element of interest, and the reference material is the upper continental crust (UCC) [Wedepohl, 1995]. To ensure the most robust results, we calculated the $\mathrm{EF}$ using $\mathrm{Fe}, \mathrm{Al}$, and $\mathrm{Ti}$ as conservative crustal elements, and used the median value to represent the EF for each sample. EF analysis allows us to differentiate elements that are enriched relative to the continental crust, as opposed to natural variations due to changes in dust sources or atmospheric transport. Elements may be enriched relative to the continental crust as defined by Wedepohl [1995] owing to natural enrichment in the regional dust, fractionation during transport from the dust source to the deposition site, or due to additional noncrustal origins such as evaporites, volcanic eruptions (explosive and quiescent degassing), or anthropogenic activities. High EFs in Cs, Bi, and $\mathrm{S}$ during the pre-industrial era suggests that these elements have additional natural sources. Potential sources of these elements are discussed below.

[13] For those elements with an increasing EF during the industrial era, it is likely that the enrichment is the result of anthropogenic activities. $\mathrm{Bi}$ and $\mathrm{U}$ are enriched relative to crustal elements post $\sim 1940$, suggesting that the increased $\mathrm{Bi}$ and $\mathrm{U}$ concentrations are caused by anthropogenic emissions of these metals (and potentially increased volcanic emissions for $\mathrm{Bi}$ [Kaspari et al., 2007]) rather than natural variations in atmospheric dust loading (Figure 3). It is notable that both peak values and background levels 
increase. EFs from 1950 to 2002 relative to $1650-1800$ have increased approximately twofold and threefold for $\mathrm{Bi}$ and $\mathrm{U}$, respectively (Table 1). Lesser 20th century EF increases are evident in Cs, and in S and Ca since 1980 . EFs for other elements show little change. This is demonstrated by plots of $\mathrm{Ti}, \mathrm{Al}$ and $\mathrm{Fe}$ concentrations and $\mathrm{EFs}$ (Figure 3). Ti, $\mathrm{Al}$ and $\mathrm{Fe}$ concentrations vary during the past two centuries owing to natural variations in the dust loading of the atmosphere, however the EFs are constant over the past three centuries. This indicates that these crustal elements have not been enriched, and provide a conservative estimate of natural dust variability. Herein we focus on those elements with an EF increase factor greater than 1.5, namely $\mathrm{Bi}, \mathrm{U}, \mathrm{Cs}, \mathrm{S}$ and $\mathrm{Ca}$.

\subsection{Comparison of the Everest Time Series With Glaciochemical Records From Other Sites}

[14] A comparison of the Everest time series with other existing records of trace element concentrations and EFs helps determine the spatial extent of the 20th century enrichment. Element concentrations and time period of peak concentrations varies between sites owing to differences in locations and element sources. We investigate sources of the enrichment and discuss potential causes for the spatial and temporal variability in the subsequent section.

\subsubsection{Bismuth}

[15] Similar to the Everest record, Bi concentrations and EFs increase from the $\sim 1950$ s to the most recent part of the records in the Muztagh Ata ice core from the Pamirs [ Li et al., 2006], in an ice core from Mount Logan, Yukon [Osterberg, 2007] (data not shown) and in snow from Coats Land, Antarctica [Planchon et al., 2002] (Figure 4). In contrast, Bi concentrations varied little in snow from Summit, central Greenland spanning 1967-1989. However, concentrations and $\mathrm{Bi} / \mathrm{Al}$ ratios during this time are fivefold and sixfold higher, respectively, than during the early Holocene [Ferrari et al., 2000]. That the enrichment is documented at multiple sites suggests that the increase in atmospheric $\mathrm{Bi}$ is widespread, but differences in the input timing of Bi between sites suggest that inputs vary regionally.

\subsubsection{Uranium}

[16] The only other $U$ time series from snow and ice are from: Mont Blanc [Barbante et al., 2001] and Colle Gnifetti [Barbante et al., 2004] in the European Alps; Coats Land, Antarctica [Planchon et al., 2002]; and Mount Logan, Yukon [Osterberg, 2007] (Figure 5). The Alps and Antarctic records are not continuous, but allow for a comparison with the Everest U record. Similar to the increase in U concentrations observed in the Everest record, Mont Blanc U concentrations increase during the 1960s to peak concentrations in the 1970s, followed by slightly lower concentrations thereafter. U concentrations in the nearby Colle Gnifetti record peak in the 1960s, earlier than the Mont Blanc and Everest record. U concentrations in the Coats Land, Antarctica record are elevated post 1900 relative to pre 1900, but no clear trend is evident. However, the Coats Land U EF record indicates enriched U post 1950, with peak U EFs in the 1980s [Planchon et al., 2002] (Figure 5). In contrast, the Mount Logan U concentrations and U EFs do not show an increase in recent decades, with post-1900 levels lower than pre-1 vels. As with $\mathrm{Bi}$, atmospheric
U enrichment appears to be widespread, but inputs vary regionally.

\subsubsection{Cesium}

[17] Previous analysis of Cs in ice cores has focused on the radioactive isotope ${ }^{137} \mathrm{Cs}$ for its use in identifying dating horizons from the atmospheric nuclear bomb tests during the $1950 \mathrm{~s}$ and $1960 \mathrm{~s}$. Here we investigate ${ }^{133} \mathrm{Cs}$, the naturally occurring stable isotope of Cs. To our knowledge the only other existing record of ${ }^{133} \mathrm{Cs}$ concentrations is from Mount Logan, Yukon. Whereas Cs concentrations and EFs are elevated since $\sim 1950$ in the Everest ice core, Cs is not enriched relative to other crustal elements in the Mount Logan ice core [Osterberg, 2007] (Figure 6).

\subsubsection{Sulfur and Sulfate}

[18] Anthropogenically emitted $\mathrm{SO}_{4}^{2-}$ aerosols greatly alter the composition of the atmosphere. These aerosols are a source of acid precipitation, and cause climate forcing by absorbing and reflecting solar radiation, and by altering cloud cover and cloud albedo [Forster et al., 2007]. Extensive research has focused on documenting atmospheric $\mathrm{SO}_{4}^{2-}$ concentrations. Numerous ice cores from northern hemisphere sites demonstrate that there has been a pronounced increase in $\mathrm{SO}_{4}^{2-}$ concentrations during the 20th century, including a large increase in background levels (Figure 7). Examples of sites showing this $\mathrm{SO}_{4}^{2-}$ increase include Colle Gnifetti [Schwikowski et al., 1999b] and Col du Dome [Preunkert et al., 2001] in the European Alps; Belukha in the Siberian Altai [Olivier et al., 2006]; Penny Ice Cap on Baffin Island [Goto-Azuma and Koerner, 2001]; Agassiz Ice Cap on Ellesmere Island [Koerner et al., 1999]; and multiple sites in Greenland [Fischer et al., 1998; Mayewski et al., 1990]. It is notable that $\mathrm{SO}_{4}^{2-}$ concentrations at all of these sites peak between the 1960s and 1970s, after which concentrations decrease.

[19] In contrast, $\mathrm{SO}_{4}^{2-}$ concentrations at Dasuopu in the Himalayas [Duan et al., 2007] and $\mathrm{S}$ and $\mathrm{SO}_{4}^{2-}$ concentrations at Mount Everest are highest during the 1980s and $1990 \mathrm{~s}$, and the magnitude of the increase is not as great as the previously mentioned sites (Figure 7). (The Everest $\mathrm{S}$ and $\mathrm{SO}_{4}^{2-}$ time series are nearly identical $(\mathrm{r}=0.92)$, thus either can be used for comparison with other ice core $\mathrm{SO}_{4}^{2-}$ records (Figures 7 and 8).) Dasuopu is located $\sim 125 \mathrm{~km}$ northwest of Mount Everest, thus similar trends in $\mathrm{SO}_{4}^{2-}$ concentrations are anticipated. However, at times background concentrations in the Everest record return to preindustrial levels, whereas in the Dasuopu record background concentrations remain elevated. These differences may be a consequence of $\mathrm{SO}_{4}^{2-}$ concentrations being twice as high at Mount Everest during both pre-industrial and postindustrial periods, which is likely due to the lower elevation of the Everest drill site (6518 $\mathrm{m}$ asl) relative to Dasuopu (7400 $\mathrm{m}$ asl). The lower background $\mathrm{SO}_{4}^{2-}$ levels at Dasuopu likely makes the site more sensitive to small concentration changes.

[20] Other Asian ice cores from the Tibetan Plateau do not show a 20th century rise in $\mathrm{SO}_{4}^{2-}$ concentrations (e.g., Dunde [Thompson and Mosley-Thompson, 1990], Guliya [Thompson et al., 1995], Puruogangri [Thompson et al., 2006], Geladandong [Grigholm, 2007]. Likewise, there is no clear 20th century rise in $\mathrm{SO}_{4}^{2-}$ concentrations in ice cores from Mount Logan [Mayewski et al., 1993; Osterberg, 2007]. However, Yalcin and Wake [2001] reported an 

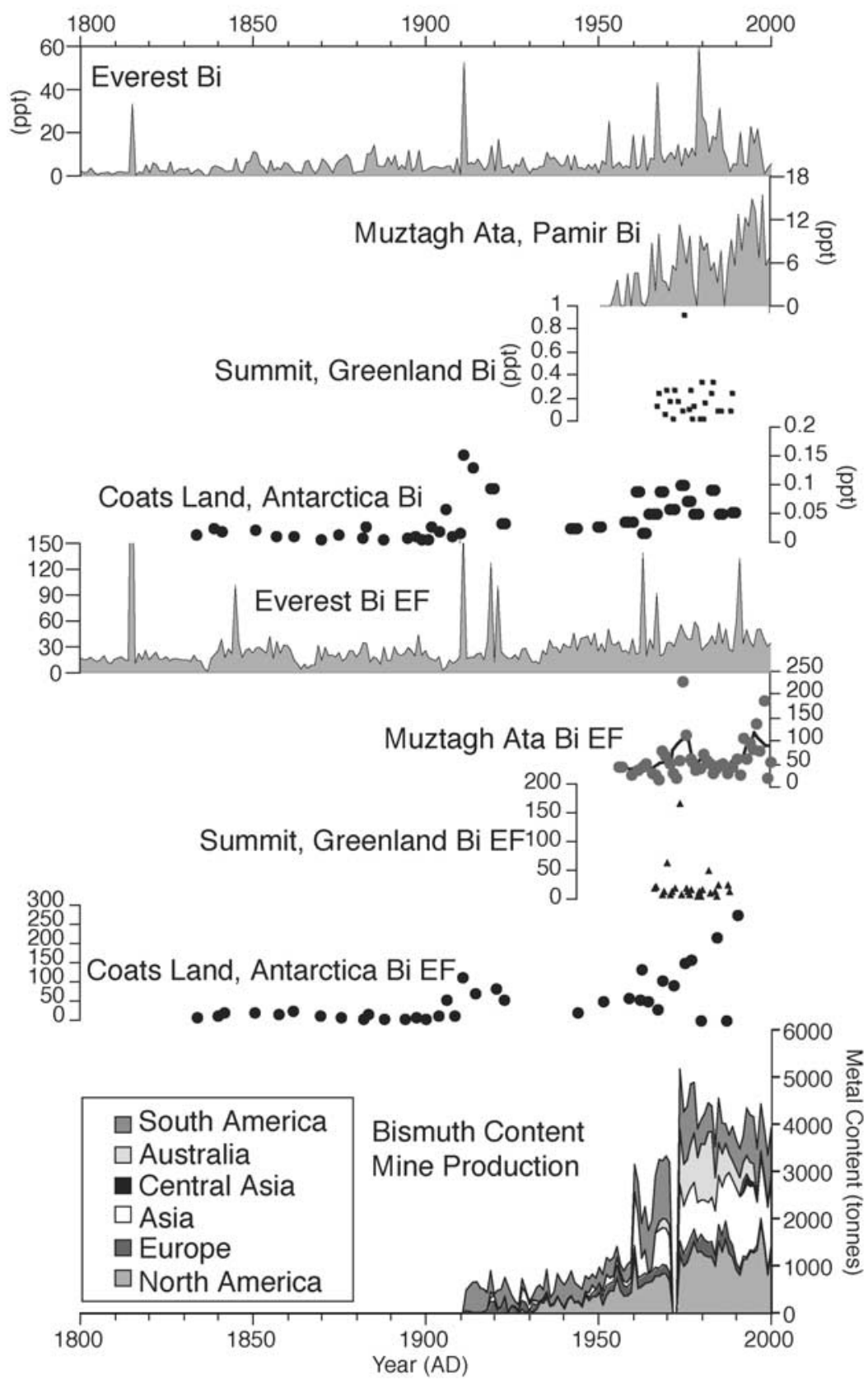

Figure 4. Mount Everest Bi and Bi EF (annual resolution) and other ice cores discussed in the text, and global Bi production (the dip in the 1970s is due to missing data).

increase in $\mathrm{SO}_{4}^{2-}$ post-1950 in the 1996 Eclipse ice core when flux corrected.

[21] Similar to EF analysis, the anthropogenic contribution to $\mathrm{SO}_{4}^{2-}$ concentrations is often quantified by calculating the mineral dust and/or sea salt portions of the total $\mathrm{SO}_{4}^{2-}$ concentrations. This is done by assuming that all of the $\mathrm{Ca}^{2+}$ and $\mathrm{Na}^{+}\left(\right.$or $\left.\mathrm{Cl}^{-}\right)$represent the mineral dust and sea salt $\mathrm{SO}_{4}^{2-}$, respectively, and is referred to as excess $\mathrm{SO}_{4}^{2-}$ and non-sea-salt (nss) $\mathrm{SO}_{4}^{2-}$. Whether mineral dust or sea salt corrections are applied depends on the sources of $\mathrm{SO}_{4}^{2-}$ for a given site. Of the before mentioned $\mathrm{SO}_{4}^{2-}$ records, Belukha, Colle Gnifetti and Col du Dome have been corrected for dust mineral inputs [Olivier et al., 2006;
Schwikowski et al., 1999a; Preunkert et al., 2001]. For Belukha and Colle Gnifetti, the $\mathrm{SO}_{4}^{2-}$ and excess $\mathrm{SO}_{4}^{2-}$ (i.e., nondust) concentration trends are largely similar since the mid-20th century because the total $\mathrm{SO}_{4}^{2-}$ signal is dominated by excess $\mathrm{SO}_{4}^{2-}$ from anthropogenic sources [Olivier et al., 2006; Schwikowski et al., 1999a] (Figure 7). Saharan dust events were generally found to have a moderate influence on $\mathrm{SO}_{4}^{2-}$ concentrations in the Col du Dome ice core [Preunkert et al., 2001]. We calculate the Everest excess $\mathrm{SO}_{4}^{2-}$ fraction: [excess- $\left.\mathrm{SO}_{4}^{2-}\right]=\left[\mathrm{SO}_{4}^{2-}\right]-$ $0.55\left[\mathrm{Ca}^{2+}\right]$, where 0.55 is the median $\mathrm{SO}_{4}^{2-} / \mathrm{Ca}^{2+}$ ratio from 1650 to 1800 . In contrast to Belukha and Colle Gnifetti, the Mount Everest excess $\mathrm{SO}_{4}^{2-}$ does not increase, likely 

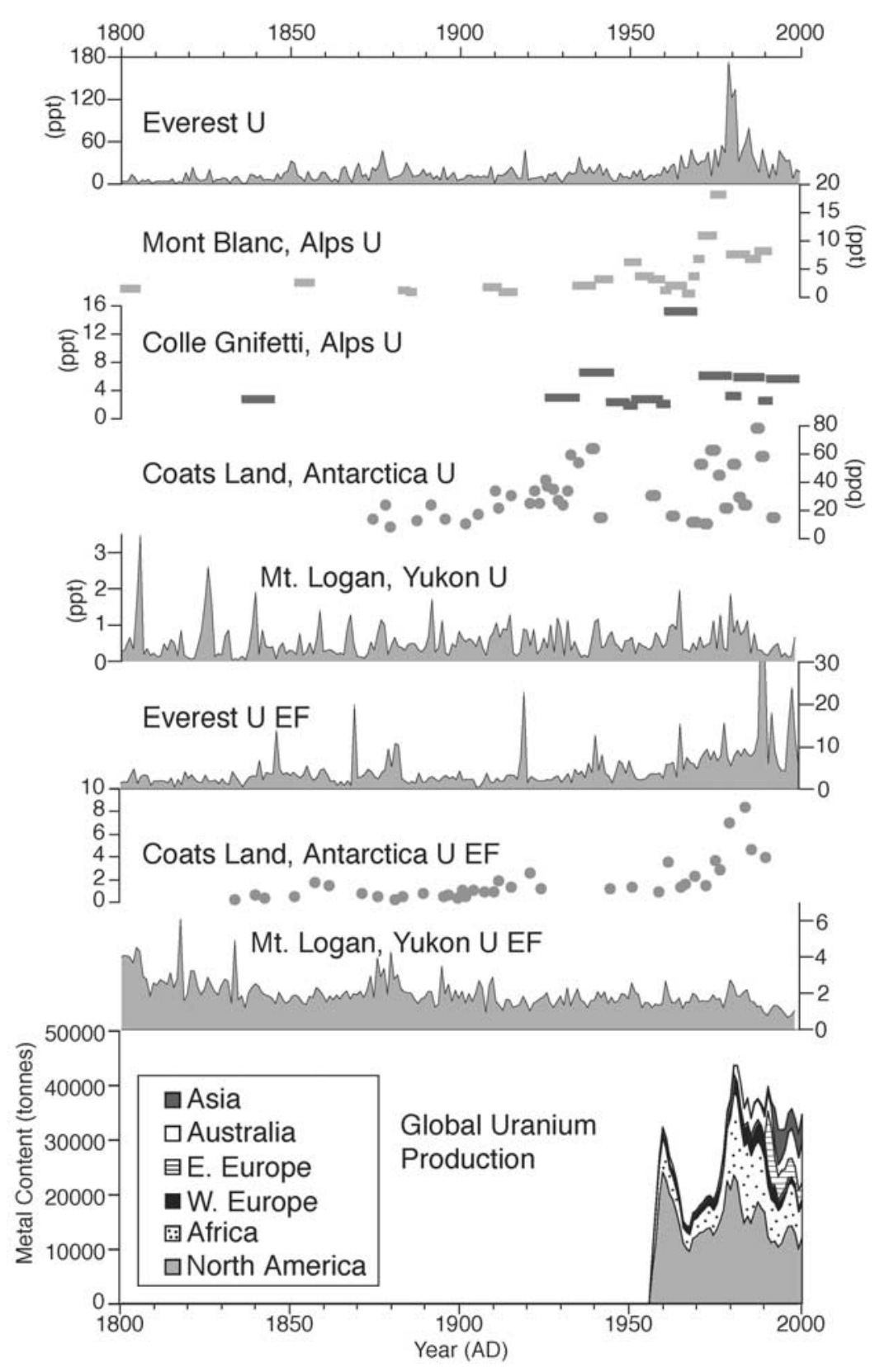

Figure 5. Mount Everest $U$ and U EF (annual resolution) and other ice cores discussed in the text, and global U production (data spanning 1956 to present; production began in the 1940s).

because the $\mathrm{SO}_{4}^{2-}$ signal is dominated by dust. However, peak Everest S EFs occur since 1989, with low S EFs during the mid-1990s (Figure 8). This suggests that the $\mathrm{SO}_{4}^{2-}(\mathrm{S})$ record at Everest may be impacted by anthropogenic sources, and is discussed in greater detail below in the section on the sources of enriched metals.

\subsubsection{Calcium}

[22] None of the ice cores previously discussed show an increase in $\mathrm{Ca}$ concentrations in recent decades similar to that observed in the Everest ice core (Table 1 and Figure 8). Mount Logan, Yukon, the only other existing record of $\mathrm{Ca}$ EFs to our knowledge, does not show a recent $\mathrm{Ca}$ enrichment. Similar EF analysis would have to be done at other sites to investigate how widespread the $\mathrm{Ca}$ enrichment observed at Mount Everest is, however ice cores from few sites have been determined for the suite of elements necessary to perform these calculations.

\subsection{Sources of Enriched Metals}

\subsubsection{Bismuth}

[23] The Everest pre-1800 median Bi EF is 18 (Table 1), suggesting a large natural noncrustal source of $\mathrm{Bi}$, namely volcanism [Candelone et al., 1995; Ferrari et al., 2000; Kaspari et al., 2007; Patterson and Settle, 1987]. On the basis of the current understanding of volcanic $\mathrm{Bi}$, quiescently degassing volcanoes are the source of the elevated background Bi EF levels, whereas large explosive volcanic eruptions that eject highly enriched $\mathrm{Bi}$ particles into the 


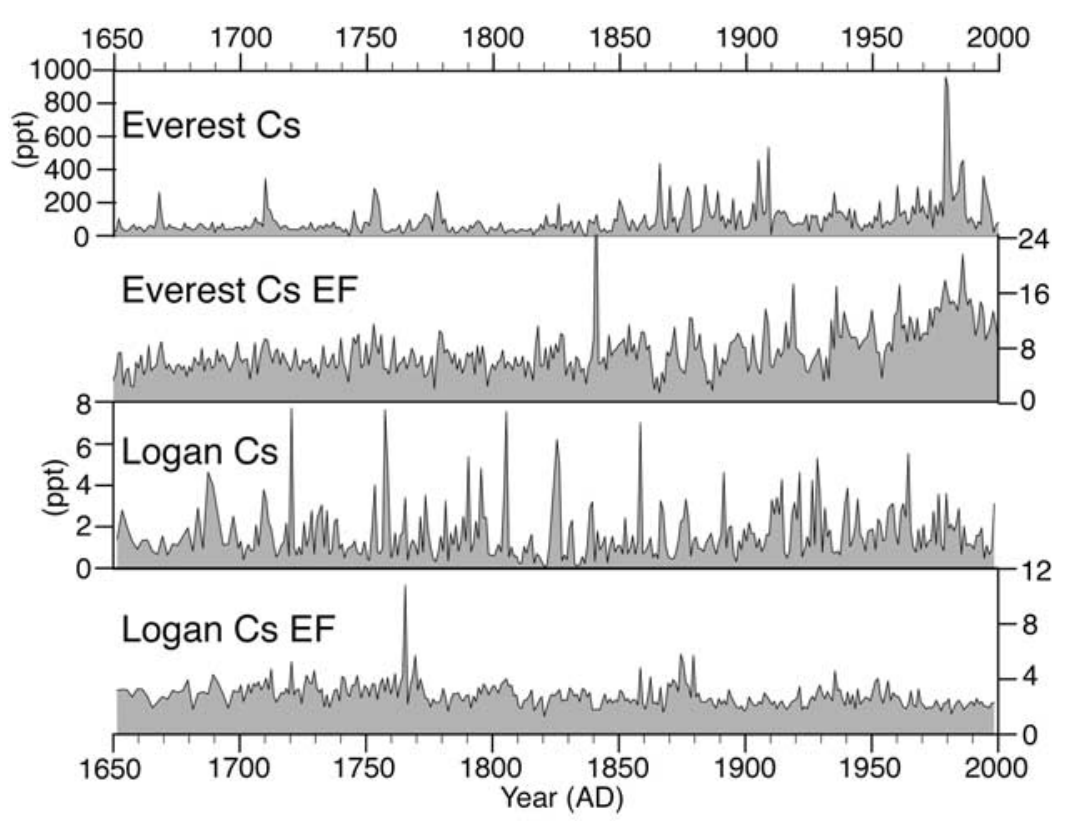

Figure 6. Annual Cs and Cs EF data for Mount Everest and Mount Logan (2-year resolution prior to 1700).

upper atmosphere are the source for large Bi peaks (Pinatubo (1991), Agung (1963) and Tambora (1815)) [Kaspari et al., 2007] (Figure 3).

[24] The enriched Bi post 1940 could be caused by both increased volcanic $\mathrm{Bi}$ emissions and anthropogenic activities. A previous study on the volcanic gas input into the atmosphere for the past 100 years found that the frequency of volcanic eruptions per year increased since $\sim 1950$ [Halmer et al., 2002]. However, it is not clear how much of this increase is due to improved monitoring rather than an actual increase in volcanic activity. Additionally, relatively little is known about volcanic Bi, thus it is not certain if an increase in volcanic gas (e.g., sulfur) emissions would translate to a similar increase in volcanic $\mathrm{Bi}$ emissions. In regions with minimal dust inputs excess $\mathrm{SO}_{4}^{2-}$ is often used as an estimate of volcanic inputs [Dixon et al., 2004]. Owing to the large dust inputs and potential anthropogenic sources of $\mathrm{SO}_{4}^{2-}$ in the Everest record, we are unable to calculate the volcanic contribution to the $\mathrm{Bi}$ record using excess $\mathrm{SO}_{4}^{2-}$.

[25] Potential anthropogenic sources of $\mathrm{Bi}$ emissions include mining and milling activities, metal smelting, oil and coal combustion, and various end uses [Ferrari et al., 2000; Brown, 2000]. Mining, milling, and high-temperature refining processes can result in the emission of large amounts of small particles that can be transported long distances in the atmosphere [e.g., Knutson and Tu, 1996; Pacyna and Pacyna, 2001]. Because Bi rarely exists in sufficient quantities to be mined as a primary product, $\mathrm{Bi}$ production is most often a byproduct of mining and processing lead and other metal ores. Common uses of Bi are in the manufacturing of alloys, chemicals, pharmaceuticals, and metallurgical additives, and more recently as a nontoxic substitute for lead [Brown, 2000].

[26] We examine historical records of the Bi content from mine production and refining to estimate anthropogenic $\mathrm{Bi}$ emissions since 1913 ( h Geological Survey's World
Mineral Statistics and World Mineral Production Series, data tables, 1913-2005) (hereinafter BGS data tables, 1913-2005). There are uncertainties in the accuracy of the historical $\mathrm{Bi}$ data because not all countries have reported $\mathrm{Bi}$ production, and $\mathrm{Bi}$ emissions from metal refinement are not well quantified. Additionally, this data does not account for important Bi sources such as $\mathrm{Pb}$ smelting. Nevertheless, the $\mathrm{Bi}$ content data provides an estimate of 20th century variations in the anthropogenic supply of $\mathrm{Bi}$, and hence potential emissions through time. The $\mathrm{Bi}$ content from mine production and refining increased substantially after the 1960 s, with global production peaking in the 1970s, and northern hemisphere production greatest during the 1970s to 1990s (BGS data tables, 1913-2005) (Figure 4). Variations in the $\mathrm{Bi}$ mine production data can be used to corroborate if the recent increases in $\mathrm{Bi}$ concentrations and EFs observed in the ice cores are related to anthropogenic emissions. The increase in $\mathrm{Bi}$ production during the late 20th century coincides with enriched $\mathrm{Bi}$ in the Everest, Muztagh Ata and Coats Land ice cores, suggesting that the recent $\mathrm{Bi}$ increase is due at least in part to anthropogenic emissions of $\mathrm{Bi}$ (as opposed to solely volcanic emissions). As mentioned previously, that the increase in $\mathrm{Bi}$ is documented at numerous sites suggests that the increased atmospheric Bi concentrations are widespread, but differences in the input timing and magnitude of these increases suggests that emissions vary regionally. Owing to uncertainties in the accuracy of the Bi production data and the lack of volcanic $\mathrm{Bi}$ emission records, the ice cores provide the best available records of spatial and temporal variations in atmospheric $\mathrm{Bi}$ concentrations through time.

\subsubsection{Uranium}

[27] The Everest pre-1800 median U EF is $\sim 2$ (Table 1), indicating minimal $U$ enrichment relative to the UCC. Previous research reported high $U$ concentrations in Himalayan river water from weathering of the Higher Himalayan Crystalline series [Rengarajan et al., 2006], which may 


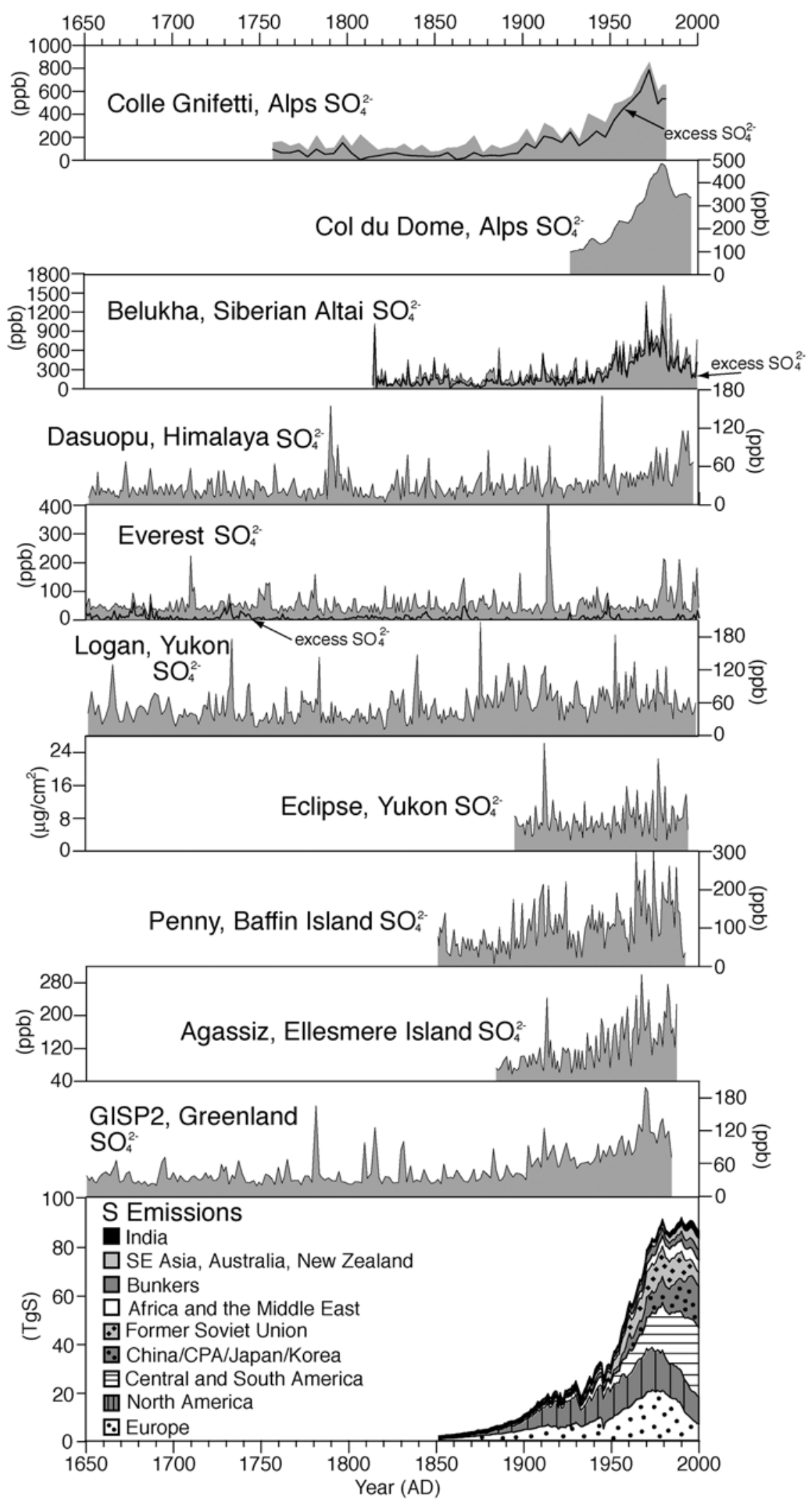

Figure 7. $\mathrm{SO}_{4}^{2-}$ data for Mount Everest (annual resolution) and other ice cores discussed in the text. Excess $\mathrm{SO}_{4}^{2-}$ data are plotted over the $\mathrm{SO}_{4}^{2-}$ data (black line) for Colle Gnifetti, Belukha, and Mount Everest. 


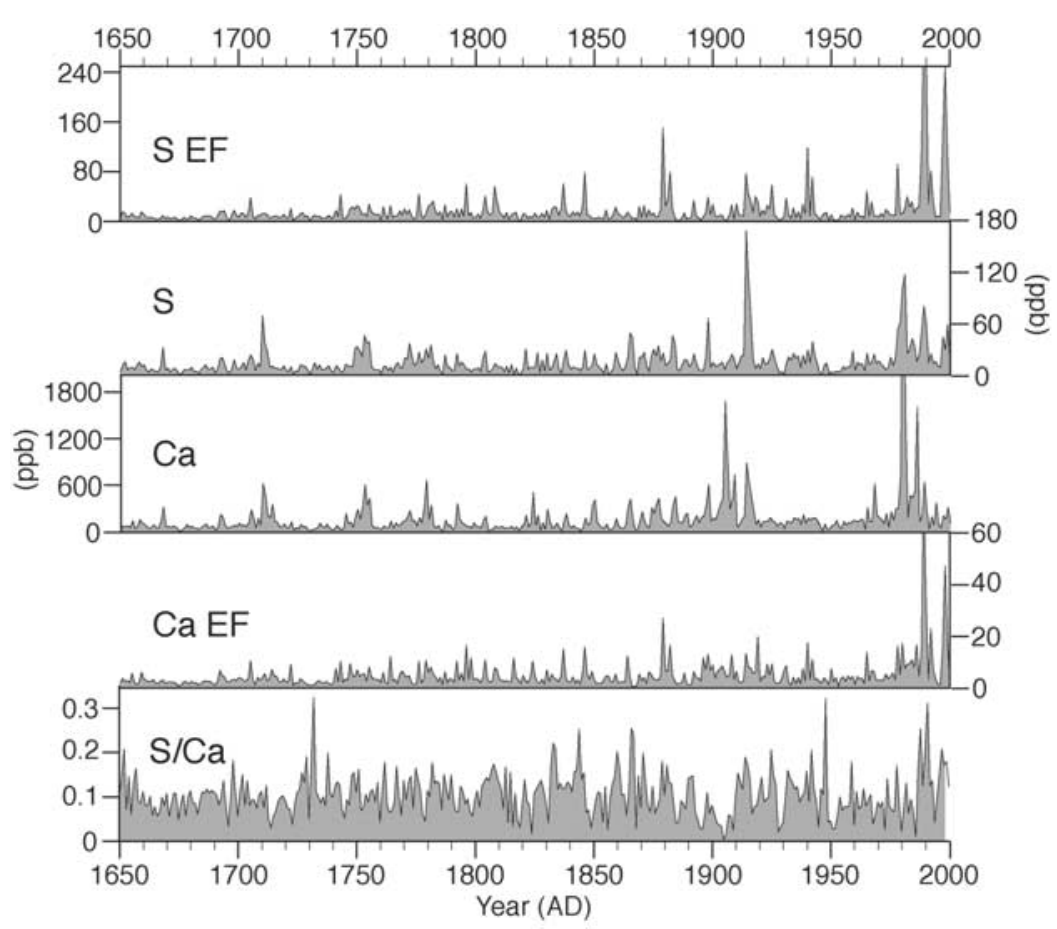

Figure 8. Mount Everest annual S, S EF, Ca, Ca EF, and S/Ca ratio.

explain the slight enrichment of $U$ in the Everest ice core from pre-industrial times.

[28] Prior to the 1940s, the most common use of U was as a dye. U became increasingly important in nuclear energy applications following the discovery in 1939 that $U$ could undergo nuclear fission. Historical records of $U$ production indicates that large-scale U production began in the 1940s and increased until peak production in the 1980s, with substantial production to present (Figure 5) (BGS data tables, 1913-2005). Not all countries have fully disclosed $\mathrm{U}$ production for political reasons, however the production data provides an approximation of regional and global $\mathrm{U}$ mining. The United States and Canada account for a large portion of global U production from the 1940s to 1980, with considerably smaller U production in western Europe and Africa. In the 1980s Australia began to produce U, as did countries in central Asia and eastern Europe in the 1990s (Figure 5). U emissions from nuclear power plants are thought to be negligible [Barbante et al., 2001].

[29] It is notable that there is no reported $U$ production in Asia prior to the 1990s, however $U$ is enriched in the Everest record beginning in the 1940s (Figure 5). On the basis of the historical $U$ production data and atmospheric circulation patterns, Europe and/or North America are the most likely source(s) of the U enrichment prior to 1990 , suggesting that $U$ may be transported long distances in the atmosphere. The enriched $U$ observed in the Everest core may be representative of widespread increases in atmospheric U. However, as stated earlier, there are regional differences in $U$ enrichment. Everest peak U EFs occur during the 1990s, coincident with U production in central Asia. Thus, the recent increase in $U$ EFs is likely due to $U$ contributions from regional mining activities. It is also notable that the increase in U EFs in Antarctica is coincident with increased U production in Africa and Australia, further supporting regional differences in $\mathrm{U}$ enrichment.

\subsubsection{Cesium}

[30] The median Everest Cs EF prior to 1800 is $\sim 8$. Studies of airborne concentrations of Cs in the 1970s from multiple sites (United States, Antarctica, Bolivia, Enewetak) had a mean Cs EF of 5.5 (std. dev. = 1.6) [Wiersma and Davidson, 1986]. The short temporal span of these studies prevents us from determining if the slight Cs enrichment is due to anthropogenic activities. However, it does indicate that atmospheric enrichment of Cs relative to the UCC may be widespread.

[31] The first anthropogenic use of Cs was in radio vacuum tubes in the 1920s. Cs consumption increased during the 1950s related to electronic applications, followed by peak Cs consumption during the 1960 s to 1980 s, with the majority of consumption occurring in the United States in developmental research. Subsequently Cs consumption fell during the 1980s and 1990s. Nearly all of the world's supply of Cs comes from Canada, however Namibia and Zimbabwe both have large Cs reserves. Smaller Cs deposits are known to exist elsewhere, including in Afghanistan, India and Tibet, however these reserves have not been worked. Compared to other elements, the mining and processing of $\mathrm{Cs}$ minerals are small [Butterman et al., 2004].

[32] The source of the elevated Cs concentrations and EF in the Everest record is not clear. However, Cs mining is minimal, and the timing of the increases in $\mathrm{U}$ and $\mathrm{Cs}$ concentrations and EFs in the Everest record is similar. Thus, the source of the atmospheric Cs enrichment could be a byproduct of mining and processing of other elements, such as U. Other anthropogenic activities such as agriculture or changes in land use could also be sources of the enriched 
Cs, however we are unaware of any previous research that supports this.

\subsubsection{Sulfate and Calcium}

[33] The median Everest S EF prior to 1800 is $\sim 9$ (Table 1). Probable sources of this enrichment relative to the UCC are mineral dust, volcanic emissions, and to a lesser degree marine aerosols. The median Everest Ca EF prior to 1800 is $\sim 2.5$; the source of this minor enrichment relative to the $\mathrm{UCC}$ is likely carbonate minerals in the regional dust.

[34] The 20th century $\mathrm{SO}_{4}^{2-}$ enrichment reported in previous ice core studies has been attributed to anthropogenic emissions of $\mathrm{SO}_{2}$, of which the dominant sources are fossil fuel burning (coal and oil), metal smelting and biomass burning. Global $\mathrm{SO}_{2}$ emissions have increased dramatically since the 1950s (Figure 7) [Smith et al., 2004]. Owing to the relatively short residence time of $\mathrm{SO}_{4}^{2-}$ aerosols in the atmosphere [Garland, 1978], $\mathrm{SO}_{4}^{2-}$ concentrations can vary greatly from region to region and over time. This is evident by the differences in timing between sites of the rise in $\mathrm{SO}_{4}^{2-}$ background levels, peak concentrations, and for some sites, decline in $\mathrm{SO}_{4}^{2-}$ concentrations in recent decades (Figure 7). The geographic sources of $\mathrm{SO}_{4}^{2-}$ for the previously mentioned ice core records are discussed in their associated references. Here we focus on the source of the increased $\mathrm{S}$ and $\mathrm{SO}_{4}^{2-}$ concentrations and $\mathrm{S}$ EF in the Everest ice core, and $\mathrm{SO}_{4}^{2-}$ variations in other Asian ice cores.

[35] The rise in $\mathrm{SO}_{4}^{2-}$ concentrations is attributed to $\mathrm{SO}_{2}$ emissions from: Siberia and Kazakhstan in the Belukha ice core from the Siberian Altai [Olivier et al., 2006]; and from Southern Asia in the Dasuopu ice core from the Himalayas [Duan et al., 2007]. It is interesting that ice cores from the Tibetan Plateau (e.g., Dunde, Guliya, Geladandong, Puruongangri), which are located between Belukha and Dasuopu, do not show a 20th century increase in $\mathrm{SO}_{4}^{2-}$ concentrations. This is likely due to two factors: (1) These sites are located further away from large population centers that are a source of $\mathrm{SO}_{2}$ emissions, and (2) high concentrations of mineral dust $\mathrm{SO}_{4}^{2-}$ sources on the Tibetan Plateau (a magnitude greater than the other northern hemisphere sites, including Everest and Dasuopu) may prevent detection of $\mathrm{SO}_{4}^{2-}$ from anthropogenic sources.

[36] As discussed previously, $\mathrm{Na}^{+}$and $\mathrm{Ca}^{2+}$ are commonly used to estimate sea salt and mineral dust contributions to the total $\mathrm{SO}_{4}^{2-}$ signal. Duan et al. [2007] report that $\mathrm{Na}^{+}$and $\mathrm{Ca}^{2+}$ concentrations are constant over the past 200 years at Dasuopu, indicating that the source of the recent rise in $\mathrm{SO}_{4}^{2-}$ concentrations at Dasuopu is from anthropogenic emissions of $\mathrm{SO}_{2}$. There is not a 20th century increase in excess $\mathrm{SO}_{4}^{2-}$ at Everest, suggesting that the recent increase in $\mathrm{SO}_{4}^{2-}$ and $\mathrm{S}$ concentrations at Everest is not related to anthropogenic emissions of $\mathrm{SO}_{2}$.

[37] However, as mentioned earlier, there are large peaks in the $\mathrm{S}$ and $\mathrm{Ca} \mathrm{EFs}$ since 1989 that are unprecedented during the 350-year record (Figure 8), and increase factor analysis for both $\mathrm{S}$ and Ca EFs indicate enrichment of these elements in recent decades (Table 1). Moreover, the variations in the $\mathrm{S}$ and Ca EFs are similar since 1989 (Figure 8), suggesting a common source for the enrichment of these two elements, of which the mostly likely source is gypsum. (Because excess $\mathrm{SO}_{4}^{2-}$ is calculated using $\mathrm{Ca}$, this explains why an increase is obse $\quad \mathrm{S}$ and $\mathrm{Ca} \mathrm{EFs}$, but not excess
$\mathrm{SO}_{4}^{2-}$. This is further supported by the $\mathrm{S} / \mathrm{Ca}$ ratio, which remains within the range of natural variability in recent decades.) If this is the case, the increase in atmospheric gypsum is unprecedented since 1650 . The molar $\mathrm{Ca} / \mathrm{S}$ ratio varies throughout the record, but is consistently higher than 1. This indicates that there are additional $\mathrm{Ca}$ inputs relative to what would be expected if gypsum was the sole source of $\mathrm{Ca}$, consistent with previous results reported at Inilchek [Kreutz and Sholkovitz, 2000]. The source of the increased $\mathrm{Ca}$ and $\mathrm{S}$ in the atmosphere in the Everest region is not certain owing to the high dust concentrations, but potential causes for the increase could be related to land use change, desertification, atmospheric reactions of $\mathrm{S}$ and carbonates, or industrial processes such as flue gas desulfurization systems that remove $\mathrm{S}$ from power plant flues and produce gypsum. Further research is necessary to test these hypotheses.

\section{Conclusions}

[38] The Mount Everest ICP-SFMS ice core record provides the first high-resolution, continuous Asian ice core record of trace elements spanning the pre-industrial period to present. Modern concentrations and EFs of most elements are still within the range of pre-industrial levels. However, owing to high dust concentrations in central and southwestern Asia, some changes in the composition of the atmosphere related to anthropogenic activities may be difficult to detect.

[39] Our findings indicate that anthropogenic activities are altering the composition of the remote Himalayan atmosphere. Median concentrations of $\mathrm{Bi}$ and $\mathrm{U}$ since 1950 are $\sim 2$ and $\sim 3$ times greater, respectively, than concentrations prior to $1800 \mathrm{AD}$, and concentrations of $\mathrm{Cs}, \mathrm{Ca}$ and $\mathrm{S}$ are $\sim 1.5-2$ times greater over the same period. EF analysis indicates that these increases are not due to natural variations in the dust concentrations of the atmosphere. The Bi enrichment may be caused by both an increase in $\mathrm{Bi}$ volcanic emissions and anthropogenic $\mathrm{Bi}$ production, refinement and end uses, whereas the U enrichment reflects an increase in global U mining and refinement for nuclear energy. The Cs enrichment has not previously been observed in other ice cores, and the source of the enrichment is less certain. However, the similarity in the timing and magnitude of the Cs and $U$ enrichment suggests that the source of the Cs may be a byproduct of mining and refinement of other elements. The source of the recent increase in $\mathrm{S}$ and $\mathrm{Ca}$ is not clear, but may be related to land use and environmental change. Comparison of the $\mathrm{Bi}$, $\mathrm{U}, \mathrm{Cs}, \mathrm{S}$ and $\mathrm{Ca}$ data with other ice core records and production data indicates that the increase in atmospheric concentrations of trace elements is widespread, but that enrichment varies regionally.

[40] Anthropogenic emissions of atmospheric trace metals in Asia are projected to increase. This research provides a record of the pre-industrial composition of the atmosphere, subsequent changes related to 20th century anthropogenic activities, and baseline data for continual monitoring of the remote Asian troposphere.

[41] Acknowledgments. This research was funded by NSF ATM 0139491, NOAA NA05OAR4311109, the Natural Science Foundation of China (90411003 and 40401054), and the Chinese Academy of Sciences ("Talents Project" and the 3rd Innovation Programs: KZCX3-SW-339/ 
344). We thank the 2002 expedition staff for their excellent work in the field, and we thank the anonymous reviewers for their comments.

\section{References}

Barbante, C., K. Van De Velde, G. Cozzi, G. Capodaglio, P. Cescon, F. Planchon, S. M. Hong, C. Ferrari, and C. Boutron (2001), Post-World War II uranium changes in dated Mont Blanc ice and snow, Environ. Sci. Technol., 35(20), 4026-4030, doi:10.1021/es0109186.

Barbante, C., et al. (2004), Historical record of European emissions of heavy metals to the atmosphere since the 1650s from Alpine snow/ice cores drilled near Monte Rosa, Environ. Sci. Technol., 38(15), 40854090, doi:10.1021/es049759r.

Boutron, C. F., and C. C. Patterson (1983), The occurrence of lead in Antarctic recent snow, firn deposited over the last 2 centuries and prehistoric ice, Geochim. Cosmochim. Acta, 47(8), 1355-1368, doi:10.1016/0016-7037(83)90294-6.

Boutron, C., U. Gorlach, J. P. Candelone, M. Bolshov, and R. Delmas (1991), Decrease in anthropogenic lead, cadmium and zinc in Greenland snows since the late 1960s, Nature, 353, 153-156, doi:10.1038/ $353153 \mathrm{a} 0$

Boutron, C. F., J. P. Candelone, and S. M. Hong (1995), Greenland snow and ice cores: Unique archives of large-scale pollution of the troposphere of the Northern Hemisphere by lead and other heavy metals, Sci. Total Environ., 160-161, 233-241, doi:10.1016/0048-9697(95)04359-9.

Brown, R. D. (2000), Bismuth, in U. S. Geological Survey Minerals Yearbook, pp. 131-134, U. S. Geol. Surv., Reston, Va.

Butterman, W. C., W. Brooks, and R. G. Reese (2004), Cesium, in Mineral Commodity Profiles, pp. 1-10, U. S. Geol. Surv., Reston, Va.

Candelone, J. P., M. A. Bolshov, S. N. Rudniev, S. M. Hong, and C. F. Boutron (1995), Bismuth in recent snow from Central Greenland Preliminary results, Atmos. Environ., 29(15), 1843-1848, doi:10.1016/ 1352-2310(95)00058-7.

Dixon, D., P. A. Mayewski, S. Kaspari, S. Sneed, and M. Handley (2004), A 200-year sub-annual record of the primary sources of sulfate in West Antarctica, Ann. Glaciol., 39, 545-556, doi:10.3189/ 172756404781814113.

Duan, K., L. G. Thompson, T. Yao, M. Davis, and E. Mosley-Thompson (2007), A 1000 year history of atmospheric sulfate concentrations in southern Asia as recorded by a Himalayan ice core, Geophys. Res. Lett., 34, L01810, doi:10.1029/2006GL027456.

Ferrari, C. P., S. Hong, K. Van de Velde, C. F. Boutron, S. N. Rudniev, M. Bolshov, W. Chisholm, and K. J. R. Rosman (2000), Natural and anthropogenic bismuth in Central Greenland, Atmos. Environ., 34(6), 941-948, doi:10.1016/S1352-2310(99)00257-5.

Fischer, H., D. Wagenbach, and J. Kipfstuhl (1998), Sulfate and nitrate firn concentrations on the Greenland ice sheet: 2. Temporal anthropogenic deposition changes, J. Geophys. Res., 103(D17), 21,935-21,942, doi:10.1029/98JD01886.

Forster, P., et al. (2007), Changes in atmospheric constituents and in radiative forcing, in Climate Change 2007: The Physical Science Basis. Contribution of Working Group I to the Fourth Assessment Report of the Intergovernmental Panel on Climate Change, edited by S. Solomon et al., pp. 1-18, Cambridge Univ. Press, Cambridge, U.K.

Garland, J. A. (1978), Dry and wet removal of sulfur from atmosphere, Atmos. Environ., 12(1-3), 349-362, doi:10.1016/0004-6981(78)90217-2.

Goto-Azuma, K., and R. M. Koerner (2001), Ice core studies of anthropogenic sulfate and nitrate trends in the Arctic, J. Geophys. Res., 106(D5), 4959-4969, doi:10.1029/2000JD900635.

Grigholm, B. (2007), Climate investigations using glaciochemical records from a Tibetan ice core and a fresh snow reconnaissance study from Tierra del Fuego, M. S. thesis, Univ. of Maine, Orono.

Halmer, M. M., H. U. Schmincke, and H. F. Graf (2002), The annual volcanic gas input into the atmosphere, in particular into the stratosphere: A global data set for the past 100 years, J. Volcanol. Geotherm. Res., 115(3-4), 511-528, doi:10.1016/S0377-0273(01)00318-3.

Hou, S., D. Qin, D. Zhang, J. Ren, S. Kang, P. A. Mayewski, and C. P. Wake (2002), Comparison of two ice core chemical records recovered from the Mt. Qomolangma (Everest) region, Ann. Glaciol., 35, 266-272, doi:10.3189/172756402781817239.

Hou, S., D. Qin, D. Zhang, S. Kang, P. A. Mayewski, and C. P. Wake (2003), A 154 a high-resolution ammonium record from the Rongbuk Glacier, north slope of Mt. Qomolangma (Everest), Tibet-Himal region, Atmos. Environ., 37(5), 721-729, doi:10.1016/S1352-2310(02)00582-4.

Kang, S., P. A. Mayewski, D. Qin, Y. Yan, S. Hou, D. Zhang, and K. J. Kreutz (2002a), Glaciochemical records from a Mt. Everest ice core: Relationship to atmospheric circulation over Asia, Atmos. Environ., 36(21), 3351-3361, doi:10.1016/S1352-2310(02)00325-4.

Kang, S., P. A. Mayewski, D. Qin, Y. Yan, D. Zhang, S. Hou, and J. Ren (2002b), Twentieth century increase of atmospheric ammonia recorded in
Mt. Everest ice core, J. Geophys. Res., 107(D21), 4595, doi:10.1029/ 2001JD001413

Kang, S., P. A. Mayewski, D. Qin, S. Sneed, J. Ren, and D. Zhang (2004), Seasonal differences in snow chemistry from the vicinity of Mt. Everest, central Himalayas, Atmos. Environ., 38(18), 2819-2829, doi:10.1016/ j.atmosenv.2004.02.043.

Kang, S., Q. Zhang, S. Kaspari, D. Qin, Z. Cong, J. Ren, and P. A. Mayewski (2007), Spatial and seasonal variations of elemental composition in Mt. Everest (Qomolangma) snow/firn, Atmos. Environ., 41(34), $7208-7218$

Kaspari, S., et al. (2007), Reduction in northward incursions of the South Asian Monsoon since $\sim 1400$ AD inferred from a Mt. Everest ice core, Geophys. Res. Lett., 34, L16701, doi:10.1029/2007GL030440.

Kaspari, S., R. Hooke, P. A. Mayewski, S. Kang, S. Hou, and D. Qin (2008), Snow accumulation rate on Mt. Everest: Synchroneity with sites across the Tibetan Plateau on 50-100 year timescales, J. Glaciol., 54(185), 343-352, doi:10.3189/002214308784886126.

Kaspari, S., P. A. Mayewski, M. J. Handley, S. Kang, S. Hou, K. Maasch, and D. Qin (2009), A high-resolution record of atmospheric dust variability and composition since $1650 \mathrm{AD}$ from a Mt. Everest ice core, J. Clim., in press.

Knutson, E. O., and K. W. Tu (1996), Size distribution of radon progeny aerosol in the working area of a dry former uranium mine, Environ. Int., 22, Suppl. 1, 617-632, doi:10.1016/S0160-4120(96)00164-X.

Koerner, R. M., D. A. Fisher, and K. Goto-Azuma (1999), A 100 year record of ion chemistry from Agassiz Ice Cap Northern Ellesmere Island NWT, Canada, Atmos. Environ., 33(3), 347-357, doi:10.1016/S13522310(98)00166-6.

Kreutz, K. J., and E. R. Sholkovitz (2000), Major element, rare earth element, and sulfur isotopic composition of a high-elevation firn core: Sources and transport of mineral dust in Central Asia, Geochem. Geophys. Geosyst., 1(11), 1048, doi:10.1029/2000GC000082.

$\mathrm{Li}$, Y., T. Yao, and N. Wang (2002), Concentrations of $\mathrm{Cd}$ and $\mathrm{Pb}$ in Malan ice core from Kekexili, Environ. Chem., 2(2), 194-196.

Li, Y., T. Yao, N. Wang, Z. Li, L. Tian, B. Xu, and G. Wu (2006), Recent changes of atmospheric heavy metals in a high elevation ice core from Muztagh Ata in East Pamirs: Initial results, Ann. Glaciol., 43, 154-159, doi:10.3189/172756406781812186.

Mayewski, P. A., and M. Legrand (1990), Recent increase in nitrate concentration of Antarctic snow, Nature, 346, 258-260, doi:10.1038/ $346258 \mathrm{a} 0$.

Mayewski, P. A., W. B. Lyons, M. J. Spencer, M. S. Twickler, C. F. Buck, and S. Whitlow (1990), An ice-core record of atmospheric response to anthropogenic sulfate and nitrate, Nature, 346, 554-556, doi:10.1038/ $346554 \mathrm{a} 0$.

Mayewski, P. A., G. Holdsworth, M. J. Spencer, S. Whitlow, M. S. Twickler, M. C. Morrison, K. F. Ferland, and L. D. Meeker (1993), Ice-core sulfate from three northern hemisphere sites: Source and temperature forcing implications, Atmos. Environ., Part A, 27(17/18), 2915-2919.

McConnell, J., and R. L. Edwards (2008), Coal burning leaves toxic heavy metal legacy in the Arctic, Proc. Natl. Acad. Sci. U. S. A., 105(34), 12,140-12,144, doi:10.1073/pnas.0803564105.

Nikolaeva, I. V., A. I. Saprykin, and S. V. Palesski (2003), ICP-MS determination of heavy metal content and isotopic composition of lead in the Altai Glaciers, J. Phys. IV, 107, 957-960, doi:10.1051/jp4:20030457.

Nriagu, J. O., and C. I. Davidson (1986), Toxic Metals in the Atmosphere, 635 pp., John Wiley, Hoboken, N.J.

Nriagu, J. O., and J. M. Pacyna (1988), Quantitative assessment of worldwide contamination of air, water and soils with trace metals, Nature, 333, 134-139, doi: $10.1038 / 333134 \mathrm{a} 0$.

Olivier, S., C. Blaser, S. Brütsch, N. Frolova, H. W. Gäggeler, K. A. Henderson, T. Palmer, T. Papina, and M. Schwikowski (2006), Temporal variations of mineral dust, biogenic tracers, and anthropogenic species during the past two centuries from Belukha ice core, Siberian Altai, J. Geophys. Res., 111, D05309, doi:10.1029/2005JD005830.

Osterberg, E. C. (2007), North Pacific late Holocene climate variability and atmospheric composition, dissertation thesis, Univ. of Maine, Orono.

Osterberg, E. C., M. J. Handley, S. Sneed, P. A. Mayewski, and K. J. Kreutz (2006), Continuous ice core melter system with discrete sampling for major ion, trace element, and stable isotope analyses, Environ. Sci. Technol., 40, 3355-3361, doi:10.1021/es052536w.

Osterberg, E. C., et al. (2008), Ice core record of rising lead pollution in the North Pacific atmosphere, Geophys. Res. Lett., 35, L05810, doi:10.1029/ 2007GL032680.

Pacyna, J. M., and E. G. Pacyna (2001), An assessment of global and regional emissions of trace metals to the atmosphere from anthropogenic sources worldwide, Environ. Rev., 9, 269-298, doi:10.1139/er-9-4-269.

Patterson, C. C., and D. M. Settle (1987), Magnitude of lead flux to the atmosphere from volcanoes, Geochim. Cosmochim. Acta, 51(3), 675681, doi:10.1016/0016-7037(87)90078-0. 
Planchon, F. A. M., C. F. Boutron, C. Barbante, G. Cozzi, V. Gaspari, E. W. Wolff, C. P. Ferrari, and P. Cescon (2002), Changes in heavy metals in Antarctic snow from Coats Land since the mid-19th to the late-20th century, Earth Planet. Sci. Lett., 200(1-2), 207-222, doi:10.1016/ S0012-821X (02)00612-X.

Preunkert, S., M. Legrand, and D. Wagenbach (2001), Sulfate trends in a Col du Dome (French Alps) ice core: A record of anthropogenic sulfate levels in the European midtroposphere over the twentieth century, J. Geophys. Res., 106(D23), 31,991-32,004, doi:10.1029/2001JD000792.

Preunkert, S., D. Wagenbach, and M. Legrand (2003), A seasonally resolved alpine ice core record of nitrate: Comparison with anthropogenic inventories and estimation of preindustrial emissions of NO in Europe, J. Geophys. Res., 108(D21), 4681, doi:10.1029/2003JD003475.

Rengarajan, R., M. M. Sarin, and S. Krishnaswami (2006), Dissolved uranium and ${ }^{234} \mathrm{U} /{ }^{238} \mathrm{U}$ in the Yamuna and the Chambal rivers, India, Aquat. Geochem., 12(73), doi:10.1007/s10498-005-1421-4

Schwikowski, M, S. Brutsch, H. W. Gaggeler, and U. Schotterer (1999a), A high-resolution air chemistry record from an Alpine ice core: Fiescherhorn glacier, Swiss Alps, J. Geophys. Res., 104(D11), 13,709-13,719, doi:10.1029/1998JD100112.

Schwikowski, M., A. Doscher, H. W. Gaggeler, and U. Schotterer (1999b), Anthropogenic versus natural sources of atmospheric sulphate from an Alpine ice core, Tellus, Ser. B, 51(5), 938-951, doi:10.1034/j.16000889.1999.t01-4-00006.x.

Schwikowski, M., et al. (2004), Post 17th-century changes of European lead emissions recorded in high-altitude alpine snow and ice, Environ. Sci. Technol., 38(4), 957-964, doi:10.1021/es034715o.

Smith, S. J., R. Andres, E. Conception, and J. Lurz (2004), Historical sulfur dioxide emissions 1850-2000: Methods and results, 14 pp., Joint Global Change Res. Inst, College Park, Md.

Thompson, L. G., and E. Mosley-Thompson (1990), Glacial stage ice core records from the subtropical Dunde ice cap, China, Ann. Glaciol., 14, $288-297$.

Thompson, L. G., E. Mosley-Thompson, M. Davis, P. N. Lin, V. Mikhalenko, and J. Dai (1995), A 1000 year ice core climate record from the Guliya Ice Cap, China: Its relationship to global climate variability, Ann. Glaciol., $21,175-181$

Thompson, L. G., T. Yao, M. Davis, E. Mosley-Thompson, T. A. Mashiotta, P. N. Lin, V. Mikhalenko, and V. S. Zagorodnov (2006), Holocene climate variability archived in the Puruogangri ice cap on the central Tibetan Plateau, Ann. Glaciol., 43, 61-69, doi:10.3189/172756406781812357.
Tian, L., V. Masson-Delmotte, M. Stievenard, T. Yao, and J. Jouzel (2001), Tibetan Plateau summer monsoon northward extent revealed by measurements of water stable isotopes, J. Geophys. Res., 106(D22), 28,08128,088, doi:10.1029/2001JD900186.

Tian, L., T. Yao, P. F. Schuster, J. W. C. White, K. Ichiyanagi, E. Pendall, J. Pu, and W. Yu (2003), Oxygen-18 concentrations in recent precipitation and ice cores on the Tibetan Plateau, J. Geophys. Res., 108(D9), 4293, doi:10.1029/2002JD002173.

Van de Velde, K., C. F. Boutron, C. P. Ferrari, A. L. Moreau, R. J. Delmas, C. Barbante, T. Bellomi, G. Capodaglio, and P. Cescon (2000), A two hundred years record of atmospheric cadmium, copper and zinc concentrations in high altitude snow and ice from the French-Italian Alps, Geophys. Res. Lett., 27(2), 249-252, doi:10.1029/1999GL010786.

Wake, C. P., P. A. Mayewski, X. Zichu, W. Ping, and L. Zhongqin (1993), Regional distribution of monsoon and dust signals in Asian glaciers, Geophys. Res. Lett., 20(14), 1411-1414, doi:10.1029/93GL01682.

Wedepohl, K. H. (1995), The composition of the continental crust, Geochim. Cosmochim. Acta, 59(7), 1217-1232, doi:10.1016/00167037(95)00038-2.

Wiersma, G. B., and C. I. Davidson (1986), Trace metals in the atmosphere of rural and remote areas, in Toxic Metals in the Atmosphere, edited by J. O. Nriagu and C. I. Davidson, pp. 201-266, John Wiley, Hoboken, N. J.

Xiao, C. D., D. Qin, T. Yao, J. Ren, and Y. Li (2001), Spread of lead pollution over remote regions and upper troposphere: Glaciochemical evidence from polar regions and Tibetan Plateau, Bull, Environ. Toxicol. 66, 691-698

Yalcin, K., and C. P. Wake (2001), Anthropogenic signals recorded in an ice core from Eclipse Icefield, Yukon Territory, Canada, Geophys. Res. Lett. 28(23), 4487-4490, doi:10.1029/2001GL013037.

M. Handley, P. A. Mayewski, E. Osterberg, and S. Sneed, Climate Change Institute and Department of Earth Sciences, University of Maine, 134 Sawyer Environmental Research Center, Orono, ME 04469, USA.

S. Hou, S. Kang, and D. Qin, State Joint Key Laboratory of Cryospheric and Environment, Chinese Academy of Sciences, Beijing, 10085 China.

S. Kaspari, Laboratory for Radiochemistry and Environmental Chemistry, Paul Scherrer Institute, CH-5232 Villigen, Switzerland. (susan.kaspari@ psi.ch) 